\title{
1 Improving estimates of tropical peatland area, carbon storage, 2 and greenhouse gas fluxes
}

3 I.T. Lawson

4 Department of Geography and Sustainable Development, University of St Andrews, Irvine Building,

5 North Street, St Andrews KY16 9AJ, UK

6 T.J. Kelly

$7 \quad$ School of Geography, University of Leeds, Leeds LS2 9JT, UK

$8 \quad$ P. Aplin

9 School of Geography, University of Nottingham, University Park, Nottingham NG7 2RD, UK

10 A. Boom

11 Department of Geography, University of Leicester, Leicester LE1 7RH, UK

12 G. Dargie

13 School of Geography, University of Leeds, Leeds LS2 9JT, UK

$14 \quad$ F.C.H. Draper

15 School of Geography, University of Leeds, Leeds LS2 9JT, UK

16 P.N.Z.B.P. Hassan

17 Department of Geography, University of Leicester, Leicester LE1 7RH, UK

18 J. Hoyos-Santillan

19 School of Biosciences, University of Nottingham, University Park, Nottingham NG7 2RD, UK

20 J. Kaduk

21 Department of Geography, University of Leicester, Leicester LE1 7RH, UK

22 D. Large

23 Department of Chemical and Environmental Engineering, University of Nottingham, University Park,

$24 \quad$ Nottingham NG7 2RD, UK

25 W. Murphy

26 Department of Geography, University of Leicester, Leicester LE1 7RH, UK

27 S.E. Page

28 Department of Geography, University of Leicester, Leicester LE1 7RH, UK 
K.H. Roucoux

Department of Geography and Sustainable Development, University of St Andrews, Irvine Building, North Street, St Andrews KY16 9AJ, UK

S. Sjögersten

School of Biosciences, University of Nottingham, University Park, Nottingham NG7 2RD, UK

K. Tansey

Department of Geography, University of Leicester, Leicester LE1 7RH, UK

M. Waldram

Department of Geography, University of Leicester, Leicester LE1 7RH, UK

B. M. M. Wedeux

Department of Plant Sciences, University of Cambridge, Downing Street, Cambridge CB2 3EA, UK

J. Wheeler

Department of Geography, University of Leicester, Leicester LE1 7RH, UK

Corresponding author: I.T. Lawson, School of Geography, University of Leeds, Leeds LS2 9JT, UK

Email: itl2@st-andrews.ac.uk

Telephone: +44 (0) 1334464023

Fax: +44(0) 1334463949

\section{Abstract}

Our limited knowledge of the size of the carbon pool and exchange fluxes in forested lowland tropical peatlands represents a major gap in our understanding of the global carbon cycle. Peat deposits in several regions (e.g. the Congo Basin, much of Amazonia) are only just beginning to be mapped and characterised. Here we consider the extent to which methodological improvements and improved coordination between researchers could help to fill this gap. We review the literature on measurement of the key parameters required to calculate carbon pools and fluxes, including peatland area, peat bulk density, carbon concentration, above-ground carbon stocks, litter inputs to the peat, gaseous carbon exchange, and waterborne carbon fluxes. We identify areas where further research and better 
coordination are particularly needed in order to reduce the uncertainties in estimates of tropical peatland carbon pools and fluxes, thereby facilitating better-informed management of these exceptionally carbon-rich ecosystems.

\section{Keywords}

Peat, greenhouse gases, remote sensing, tropical ecology, carbon cycle.

\section{Introduction}

Most peat in the tropics is located in the lowland humid forests of Southeast Asia, Amazonia, Central America and equatorial Africa (Figure 1). Page et al. (2011b) estimated the extent of tropical peatlands at $441,000 \mathrm{~km}^{2}$ and their carbon (C) pool at 81.7-91.9 Gt C. This carbon pool is susceptible to climate change as well as local human impacts. Some peatlands in inland regions of Kalimantan have lost carbon due to increasing El Niño intensity and changing sea levels during the late Holocene (Dommain et al. 2011,2014), suggesting that these peatlands may also respond to future (anthropogenic) climatic change. More recently, peatlands throughout Southeast Asia have been degraded by logging and plantation development (Miettinen et al. 2012). Drainage to improve growing conditions for crops such as oil palm and Acacia (for pulpwood) leads to peat subsidence and enhanced $\mathrm{CO}_{2}$ emissions persisting over decades (Jauhiainen et al. 2012; Hooijer et al. 2012). Accidental burning, due mainly to small-scale land clearance fires getting out of control, can lead to very large peat losses over weeks or months (e.g. in the exceptional El Niño year of 1997, $\mathrm{CO}_{2}$ emissions from Southeast Asian peatland fires were equivalent to $13-40 \%$ of total global fossil fuel emissions: Page et al. 2002). Crucially, whilst a large proportion of lost tropical forest biomass can be recovered within decades in secondarygrowth forest (Letcher and Chazdon 2009), restoration of peatland carbon stocks to pre-disturbance levels would take thousands of years.

Despite their importance, basic information on carbon storage in tropical peatlands is lacking. This is not just a problem in the tropics. Reviewing estimates of the size of the boreal peatland carbon pool, Vasander and Kettunen (2006) showed that they vary by an order of magnitude (from 41.5 Pg C for all 
histosols globally: Buringh 1984, to 455 Pg C for boreal and subarctic peatlands: Gorham 1991) due mainly to substantial variation in estimates of peat dry bulk density (DBD) and thickness. The same problem applies in the tropics but with the additional difficulty that, unlike in boreal peatlands, the area of peat is also very poorly known in some regions.

Most research in the tropics has focused on Southeast Asian peatlands, and their distribution is comparatively well known, yet large uncertainties still exist in estimates of the amount of carbon stored in them. For example, published figures for Indonesia include 37.2 (Wahyunto et al. 2003, 2004, 2006), $55 \pm 10$ (Jaenicke et al. 2008), and 57.4-58.3 Pg C (Page et al. 2011b), based on differing methodologies. New field data can make a substantial difference: Dommain et al. (2014) estimated the peatland carbon pool in western Indonesia (excluding Papua) at 23.1 Pg C, a substantial downward revision of the $33.3 \mathrm{Pg}$ C estimate for the same area by Wahyunto et al. $(2003,2004)$ due mainly to new data on DBD and peat thickness, even though the area of peat estimated by the two studies (which are based on similar GIS datasets) was almost identical (131500 and $129700 \mathrm{~km}^{2}$ respectively). Peatlands in other tropical regions are less well mapped. For example, although wetlands in the Cuvette Centrale of the Congo Basin, the fourth- or fifth-largest wetland on Earth (Campbell 2005), have been mapped using remote sensing techniques (e.g. Bwangoy et al. 2010; Betbeder et al. 2014), the extent of peat within these wetlands is essentially unknown; published estimates of the size of the peatland carbon pool in the Congo basin are based on very few field data (Joosten et al. 2012). In Amazonia, the existence of c. $40000 \mathrm{~km}^{2}$ of peat in the Pastaza-Marañón basin, Peru, has only recently been confirmed by fieldwork (Lähteenoja et al. 2009a,b, 2012). The uncertainty in this peat carbon pool is very large (0.8-9.5 Gt: Lähteenoja et al. 2012). Limited surveys have been carried out in parts of Brazil (Lähteenoja et al. 2013) and French Guiana (Cubizolle et al. 2013), but remain to be conducted elsewhere in the Amazon basin. A substantial revision of the global estimate of the size of the tropical peatland carbon pool is therefore likely over the next few years. Data on carbon fluxes, especially of the important greenhouse gas (GHG) methane, are likewise extremely scarce, especially outside Southeast Asia. 
The high carbon density of tropical peatlands makes them an obvious focus for emissionsmanagement schemes such as the UN REDD+ (United Nations Reducing Emissions from Deforestation and Forest Degradation) programme (Murdiyarso et al. 2010). This will require precise inventories of peatland carbon stocks and fluxes to be carried out for specific regions in order to provide accurate estimates of baseline carbon pools and fluxes against which projected reductions in carbon emissions can be measured, verified, and translated into carbon credits.

Therefore two fundamental research priorities are (1) to quantify the amount of carbon stored in tropical peatlands accurately at a range of scales, and (2) to quantify fluxes of carbon to and from the tropical peatland carbon pool. More broadly, a better understanding of the present distribution of tropical peatlands, the processes of peat accumulation and decay, and the development of peatlands over time is relevant to other important research questions, including:

- What determines the distribution of peat in the tropics?

- How will tropical peat stocks change in the future?

- How do tropical peatlands influence biogeography and biodiversity?

- How should tropical peatlands be managed?

In this paper we aim to encourage better and more consistent methodologies for producing carbon inventories and budgets, principally at a regional scale. The value of a coordinated approach is clear: for example, where long term, repeated and systematic carbon inventories of tropical forest biomass have been coordinated by the RAINFOR (Malhi et al. 2002) and AFRITRON networks (among others), many new insights into long- (Baker et al. 2004) and short-term (Lewis et al. 2011) carbon dynamics have emerged, generating over 100 carbon-focused publications by more than 200 collaborators.

The paper is divided into three parts, 1) mapping peat distribution, 2) estimating the size of the carbon pool, and 3) estimating carbon fluxes. In part 1, we focus on emerging remote sensing technologies which, alongside appropriate measurements on the ground, can improve our ability to map peatland extent. In part 2 we discuss the measurement of peat thickness, peat bulk density and carbon concentration. In part 3 we discuss carbon fluxes into and out of peatland ecosystems, specifically, 
long-term carbon accumulation rates, litter inputs and decomposition, gaseous and waterborne fluxes, and above-ground carbon stocks. We focus on forested tropical lowland peatlands, although we recognize that many of the issues we discuss also pertain to other types of peatland in the tropics and beyond.

\section{Mapping peat distribution}

Field mapping of peatlands is a considerable challenge, especially at regional, national and global scales. However, a combination of field measurements and inferences from remote sensing can provide an optimal balance, where realistic programmes of fieldwork can yield map-based products that cover a region comprehensively, are reasonably accurate and reliable, and with robustly quantified uncertainties.

Tropical peatlands are often distinct from surrounding terra firme (dry-land) forests in four ways that are observable in satellite and airborne data. Firstly, their vegetation is often low in diversity. In South and Central America, some parts of Africa, and on the island of New Guinea, palms are often more abundant than in upland forests, sometimes forming mono-dominant stands (e.g. Lähteenoja and Page 2011; Wright et al. 2011). However, diversity in some peatland forests can be high (e.g. Sumatran swamps: Brady 1997). Secondly, vegetation structure is often (but not always) distinctive, often with more open canopies and low-stature or thin-stemmed trees, or no trees at all (e.g. Anderson 1983; Page et al. 1999; Phillips et al. 1997). Thirdly, their topography can be distinctive. Tropical peatlands typically occupy a specific topographic or geological setting, for example the subsiding PastazaMarañón basin in Peru or the peats forming along dendritic drainage channels in the Tasek Bera basin, Malaysia (Wüst and Bustin 2004); blanket peats that are indifferent to topography only occur rarely in upland settings (Gallego-Sala and Prentice 2012). Many tropical peatlands are also detectably domeshaped (e.g. Phillips et al. 1997; Jaenicke et al. 2008; Lähteenoja et al. 2009b). Finally, peatland water tables often lie close to, at or above the surface throughout the year (e.g. Lawson et al. 2014). Whilst any one of these four features alone is insufficient to characterise an area of forest as potentially peatforming, the combination of two or more presents a much stronger case (Draper et al. in press). 
These properties can be mapped using a number of different remote sensing products. Compositional and structural features of peatland vegetation have been distinguished using optical sensors such as Landsat (Phua et al. 2007; Jaenicke et al. 2010; Li et al. 2010; Lähteenoja and Page 2011), SPOT (Systeme Pour l'Observation de la Terre; Lee 2000; Miettinen and Liew 2010), and MODIS (Moderate Imaging Spectrometer; Langner et al. 2007; Wijedasa et al. 2012). Figure 2 presents an example of vegetation classification of the Changuinola peat dome in San San Pond Sak, Panama, using multi-scale Landsat Thematic Mapper (TM) image analysis supported by aerial photography and field data to characterise the main vegetation gradient. To date, optical imagery from medium spatial resolution sensors such as the Landsat series (30 m multispectral imagery) has been the primary and most successful tool for mapping peatlands. The new generation of VHR (very high resolution) products, such as IKONOS (4 m multispectral) or WorldView-2 (2 m multispectral) imagery, potentially brings new opportunities for detailed and accurate vegetation mapping. One key difficulty in the tropics is the infrequent temporal coverage of these sensors, which makes cloud-free images difficult to obtain. RapidEye (5 m multispectral) products, derived from a constellation of five satellites with consequently more frequent image acquisition, can be a more reliable source of cloud-free imagery (e.g. Franke et al. 2012). Opportunities are likely to grow further as new sensors are launched (e.g. $1.24 \mathrm{~m}$ resolution WorldView-3) and future missions become operational (e.g. the EU's Sentinel-2 10 $\mathrm{m}$ resolution twin satellites),

Active sensors such as radar and LiDAR (Light Detection And Ranging) which penetrate the canopy can be used to detect the distinctive forest structures (e.g. combination of low canopy, thin stems, high stem density in pole forest) or patterns in structure (e.g. concentric zonation of vegetation communities) that characterize some peatlands. Radar and LiDAR are also able to provide topographic data which can help to distinguish between peatland and terra firme forests, but few attempts have been made to identify tropical peatlands using these tools. One useful exception is the use of an orbital LiDAR instrument onboard the ICESAT satellite to measure peat topography and forest biomass at a study site in Kalimantan (Ballhorn et al. 2011; other examples include Hoekman and Vissers 2007; Rakwatin et al. 2009; Jaenicke et al. 2008; Jubanski et al. 2013). A limitation of LiDAR products is that they are generally available as discrete point measurements (orbital sensors) or thin strips of data 
(aerial sensors) rather than a full coverage. Other data sources (e.g. L-band radar data and groundbased measurements of forest structure) are usually needed to interpolate between LiDAR measurements (Mitchard et al. 2012).

The presence of standing water below a forest canopy can produce a distinctive radar backscatter signal, particularly at longer radar wavelengths. L-band radar has been used extensively in tropical contexts to map standing water (de Grandi et al. 1998, 2000; Hess et al. 2003; Hoekman 2007; Bwangoy et al. 2010), to track changes in floodwater extent (Rosenqvist and Birkett 2002; Alsdorf 2003; Jung et al. 2010; Lee et al. 2011; Betbeder et al. 2014), and, using time series of radar data, to distinguish areas that are constantly wet from those that are only seasonally wet (Waldram 2014).

Remote sensing therefore already provides effective tools for extrapolating from field measurements to map peatlands over large areas, but there is scope for further methodological research. The use of optical sensors to define peatland extent has been widely and successfully implemented, but the less commonly used active sensors may discriminate between peatland and terra firme more effectively in many circumstances. We recommend that wherever possible, multiple remote sensing products (including both optical and active sensors) should be used in combination. Some of the data types discussed here, such as airborne LiDAR, are too expensive to obtain for many projects. However, suitable products for mapping peatlands based on vegetation structure and composition, topography and inundation at a coarse scale $($ c. $30 \mathrm{~m}$ ) are freely available from Landsat, SRTM (Shuttle Radar Topography Mission) and ALOS PALSAR. A combined approach using these products is a highly feasible starting point for future mapping projects.

It remains the case, however, that interpretations of peatland distribution based on remote sensing need to be validated with ground reference data. Ground reference points are often difficult and expensive to install and therefore require careful planning in order to maximise their usefulness. They need to meet many criteria: they should be widely distributed across the study region, encompassing the full range of spatial heterogeneity; they need to span the full range of environments present in the landscape (including anthropogenic ones such as rice fields and oil-palm plantations: Miettinen et al. 2012), not just those associated with peat; and the reference dataset should be sufficiently large both 
to develop and validate a classification using different subsets of the data. Typically, hundreds of points are required to develop a reliable classification for a particular region, so it would clearly be desirable if researchers visiting new sites could collaborate in generating suitable data. In Table 1 we recommend a set of measurements that are needed for synoptic mapping and ground reference, and which can easily and quickly be collected as part of the basic site description for any kind of research on tropical peatlands. More extensive and specialized measurements (e.g. detailed vegetation composition, water table depth variation) may be necessary for more specific applications of remote sensing, but wherever possible they should be carried out in a way that preserves the compatibility of measurements between studies, in line with Table 1.

\section{Carbon stocks}

The quantity of carbon stored by peatlands in a region $\left(M_{c}\right.$, in $\left.\mathrm{kg}\right)$ can be calculated as:

$$
M_{c}=A D \rho c
$$

where $A$ is the area of peatland $\left(\mathrm{m}^{2}\right), D$ represents its mean thickness $(\mathrm{m}), \rho$ is the mean DBD $\left(\mathrm{kg} \mathrm{m}^{-3}\right)$ and $c$ is its carbon concentration (dry mass proportion; Gorham 1991). The area of peatland can be determined by a combination of remote sensing and ground survey, as discussed in Section II. The remaining three variables on the right hand side of equation (1) are each susceptible to considerable uncertainty, which in combination can lead to very large uncertainties in $\mathrm{M}_{\mathrm{c}}$.

\section{Peat thickness}

In carbon inventory research it is usually convenient to treat peat as a separate, particularly carbonrich category of soil, but a long-standing problem in peat research, unlikely to be resolved any time soon, is how to define 'peat'. Most workers define a peat soil as one that contains more than a certain proportion of organic matter, but the critical value varies widely, between about 30 and 65 wt $\%$ organic matter (Joosten and Clark 2002:41; Wüst et al. 2003), hindering data synthesis (Page et al. 2011b). Some peat units have a clearly-defined contact with the underlying, less organic material, but others change in composition more gradually. In such cases it can be impossible to judge peat 
thickness consistently in the field, and unfortunately, core samples are not always taken for laboratory analysis of organic matter content, resulting in unreliable data. Researchers must acknowledge that 'peat' is de facto a flexible term, and circumvent definitional issues by collecting objective data on the properties of the material they are studying. One way forward, and our recommendation, is to build on past efforts such as the CARBOPEAT project (http://www.geog.le.ac.uk/carbopeat) to compile the necessary data (core location, sample depth, and sample loss-on-ignition and carbon concentration) to allow reanalysis using a standardized definition of 'peat'.

Estimates of peat thickness for a region are usually based on limited numbers of measurements, which may be biased by over-reporting of the thickest deposits. The geometry of peatlands is such that thick peats are often restricted to quite small areas (the centre of domed mires or basin-filling swamps) surrounded by much more extensive areas of shallow peat. Simply taking the mean of a series of measurements from the edge to the centre of a single peatland is likely to result in an overestimate of the mean peat thickness. A much more robust approach is that taken by Dommain et al. (2014), building on existing detailed GIS maps of Indonesian peatlands by Wahyunto et al. $(2003,2004,2006)$. By interpolation between field measurements, they defined GIS polygons of small areas of peat of different mean thicknesses. The total volume of peat was then derived by multiplying the area of each polygon by its specific thickness. This provides a useful template for future work, not least because the link between field data and estimates of carbon storage is explicit, facilitating revisions as further data emerge. GIS datasets can also be readily shared and assimilated into larger-scale mapping or reanalysis projects, and are thus a very desirable form of research output.

There are few detailed studies of the geometry of individual tropical peatlands, but the exceptionally detailed survey using a dense grid of 194 depth estimates across a 235 ha swamp, the CICRA peatland in southern Peru (Householder et al. 2012), demonstrates that useful insights can be gained that can guide more representative sampling of other peatlands in the region. In this case, comparison of the peatland volume estimate derived from the entire network of points showed that less detailed estimates of the volume of the same peatland based on short transects tended systematically to 
overestimate the total peat volume. This 'calibration' was then used to adjust volume estimates based on transect data only from other sites in the region.

266 Ground penetrating radar (GPR) could also be used alongside manual coring to determine peat 267 thickness and stratigraphy, and may be especially useful for studying features such as voids which can 268 be important in volume terms in forested peatlands (e.g. Slater and Reeve 2002; Parry et al. 2014). 269 There are, however, considerable practical difficulties associated with deploying relatively bulky GPR over large distances in forested peatlands, though smaller instruments are currently in development.

Few attempts have so far been made in the tropics to derive peat thickness by remote sensing, and they are exceptional cases. For example, Jaenicke et al. (2008) integrated Landsat Enhanced Thematic Mapper (ETM+) and SRTM data, a network of 750 field measurements of peat thickness, and a threedimensional peatland development model to estimate the volume of domed peatlands in Kalimantan; the success of this project depended on the rather special properties of the mires in question (regular shape, very thick peats). Ballhorn et al. (2009) also used LiDAR measurements to estimate changes in peat thickness over time due to burning on Indonesian peatlands. A more generally applicable method for measuring peat thickness remotely is perhaps unlikely to emerge but there is scope for further investigation on a site-by-site or region-by-region basis. Peat thickness can sometimes correlate with other properties that are visible by remote sensing. For example, thick peats often occur towards the centre of ombrotrophic peat domes. Field observations suggest that these deep, nutrient-poor peats are frequently (but not always) associated with specialized and structurally distinctive vegetation communities in, for example, Kalimantan (Page et al. 1999), Panama (Sjögersten et al. 2011), Peru 284 (Kelly et al. 2013; Draper et al. in press), and the Republic of Congo (G. Dargie unpublished data). 285 These plant communities are often distinctive in Landsat TM, ALOS PALSAR and other imagery. 286 However, apparent relationships between remote sensing data and peat thickness must be confirmed using empirical data because many factors other than peat thickness may be equally or more 288 important in controlling vegetation composition and structure (Draper et al. in press), as is the case in 289 temperate/boreal peatlands (Wheeler and Proctor 2000). 
291 Measured values of dry bulk density (DBD) for individual peat samples from Indonesia vary by almost 292 an order of magnitude, and the few available data from undisturbed sites in Amazonia vary by a factor 293 of two (all in peats with ash contents <10\%; Figure 3). This variability, which arises from factors 294 including the botanical composition of the peat, consolidation of deeper peats, drainage history, and measurement method, is a major source of uncertainty in estimates of the size of the peatland carbon pool because calculations of carbon stocks at individual sites, or even across regions, are frequently based on the mean of a very small number of DBD measurements (e.g. Page et al. 2011b; Householder et al. 2012).

Frequently, the number of samples taken may be too small, and/or the spacing between samples may be too large to capture the spatial variability of peat DBD. Within-site lateral variation in DBD has not been explored systematically in tropical contexts and more work is needed to establish whether there are any predictable patterns. Sometimes the stratigraphic profile of DBD is quite consistent at sites within a region (Hooijer et al. 2012), but DBD can also vary systematically between peatland types within a region (e.g. floodplain peatlands, domed peatlands; Shimada et al. 2001). The converse has been shown in boreal peatlands (i.e. DBD varies between regions within the same peatland type; Sheng et al. 2004; Yu 2012; there are insufficient data to know if this also applies in the tropics). Sitespecific measurements are therefore always desirable, and in general more data are needed to determine whether DBD varies spatially in a predictable way.

A further complication is that tropical peatlands can show considerable stratigraphic variation in DBD (Figure 4) due to fluvial mineral inputs (Lähteenoja et al. 2009b), long-term vegetation succession and related variations in peat structure (Phillips et al. 1997; Roucoux et al. 2013), peat decomposition, post-drainage consolidation (Hooijer et al. 2012), and water- or gas-filled voids. This stratigraphic variation can only be addressed through field measurements and ample down-core sampling. A greater palaeobotanical insight into the origins of variation in DBD in tropical peats would also be a useful line of research. 
A second potential source of error in DBD estimation is that peat samples of known volume must be recovered, which is difficult to achieve reliably. One method for collecting volumetric samples is to dig a pit into the peat and extract a monolith from the pit wall (Hooijer et al. 2012; Couwenberg and Hooijer 2013), but this may entail continuously pumping water out of the pit which can be impractical, is limited to shallow sections, and, by analogy with what is known of the effects of seasonal changes in water table on peat volume in undisturbed peats (Price 2003), may lead to compaction and overestimation of DBD. Various specialised corer designs have been proposed to improve the collection of volumetric samples from shallow peats (Wright et al. 1984; Givelet et al. 2004; van Asselen and Roosendaal 2009; see De Vleeschouwer et al. 2010 and Glaser et al. 2012 for discussion of the relative merits of different devices). At present, most workers use a Russian-type corer which is suitable for use in shallow and deep peats; as a side-sampling device it offers better control over sample depths than a piston corer and a low risk of sample contamination than a Hiller corer, which is especially important if the peat is to be radiocarbon dated (cf. Glaser et al. 2012), but can be less effective at cutting through woody peats than a corer with a serrated barrel. The volume of the in situ peat sample is usually assumed to be identical to the internal volume of the corer. In reality, core recovery is often imperfect, especially in fibrous or woody peat that cannot be cut cleanly, or where the peat is structurally weak and is not retained within the corer, or (in the case of piston corers) it fails to fill the barrel (Wright 1991; Dommain et al. 2011; Lähteenoja et al. 2013). Thus, DBD measurements are probably often subject to large errors stemming from erroneous volume estimations. Russian-type corers in particular may yield systematic underestimates of DBD (Clymo 1983). In general, largevolume corers (including wide-diameter Russian corers) are to be preferred over smaller devices because they will more likely retrieve a representative sample, but they can be impossible to use in stiff or woody peats and are more logistically problematic compared with a smaller, lighter device. As yet, there have been few systematic comparisons of different methods to assess the extent of the uncertainty in volume measurements (Pitkänen et al. 2011), especially in fibrous and woody peats. More research on this topic could help to quantify and, perhaps, compensate for any differences between datasets that are due to the use of different sampling devices. 
A third way in which DBD measurements made by different research groups may vary stems from variation in laboratory methods, for example in the temperature at which the peat samples are dried. Chambers et al. (2011) proposed a protocol for measuring DBD and other basic variables (including drying at $100^{\circ} \mathrm{C}$ ) which we recommend and which, if followed, will minimize this uncertainty.

\section{Carbon concentration}

Two principal approaches are used to estimate carbon concentration in peats. The more accurate and direct technique is elemental analysis (Nelson et al. 1996; Chambers et al. 2011). In peats with low ash content the carbon concentration calculated by this method typically varies between about 52 and 58\% (Figure 5). However, many workers use mass loss-on-ignition (LOI; Heiri et al. 2001) as a costeffective way to estimate organic matter concentration. The LOI at (typically) $450^{\circ} \mathrm{C}$ is assumed to be attributable to combustion of organic material; the remainder, the 'ash', is typically composed of sedimentary mineral material and biogenic silica. Carbon concentration can then be estimated by assuming that the organic material contains (e.g.) $50 \mathrm{wt} \% \mathrm{C}$ (Turunen et al. 2002).

On the basis of available data, applying the LOI-based approach described by Turunen et al. (2002) could apparently systematically underestimate carbon concentration by c. 8 wt $\%$ in tropical peats with very low ash contents (Figure 6). This disparity is principally attributable to the varying abundance of carbon-rich compounds, such as lignin or charcoal, in the organic matter fraction of peat. However, at least at some sites, the paired measurements show a strong linear relationship, albeit with some scatter. There may even be a strong linear relationship between DBD and carbon density (the product of carbon concentration and DBD, measured in e.g. $\mathrm{kg} \mathrm{C} \mathrm{m}^{-3}$ ), sufficient to support the suggestion that DBD measurements alone may be sufficient for a first-order estimate of carbon concentration (Warren et al. 2012; Farmer et al. 2013). However, the strength of this relationship varies and it has not been tested for tropical peats outside a few locations in Southeast Asia.

Therefore, for inventory purposes, and especially when undertaking work for the first time at a new site, in our view it remains important to measure carbon concentration as accurately as possible, i.e. using an elemental analyser following Chambers et al. (2011). LOI remains a useful tool in its own 
right because it provides a direct measure of the organic matter content of the peat, which is valuable in understanding the developmental history of a site. As with DBD, systematic studies of within- and between-site variation in carbon concentration are lacking in tropical contexts.

The question of the number of samples to take, both horizontally and vertically, for DBD and carbon concentration in a peatland is inevitably constrained by the resources available for a given project. One approach to designing a sampling strategy is to assess the way in which the variation in different measurements (DBD, carbon concentration, peat thickness) contributes to the overall uncertainty in the estimate of the carbon pool. For example, peat thickness is usually much more variable across a region than DBD or carbon concentration, suggesting that a rational use of research effort would be to focus on measuring peat thickness. Resampling techniques can be used to estimate the confidence interval around an estimate of the regional carbon pool for a given region (Manly 2007; Draper et al. in press). Chimner et al. (2014) discussed the relative merits of different core sub-sampling approaches in terms of attempting to encompass stratigraphic variation in DBD and carbon concentration in Canadian peats and found that, in Canada, (a) several different approaches gave similar results and (b) analysis of the DBD and carbon concentration of a single core section, from $25-75 \mathrm{~cm}$ depth at each site, gave estimates of the total peat carbon stock that were within $15 \%$ of estimates based on exhaustive sampling of entire cores from the same sites, suggesting that even a single (admittedly large) sample from each core site may be adequate for inventory purposes. This conclusion must be tested before being applied in other regions where, for example, frequent admixture of clay in deeper peats may give very different results. In general we would recommend a more conservative approach, taking several discrete subsamples throughout the full thickness of the peat (the "intermittent peat sampling method" described by Chimner et al. 2014).

\section{Biomass}

A widely-used set of standard protocols has been developed for measuring above-ground biomass (AGB) in terra firme tropical forests (e.g. Phillips et al. 2009). These protocols are, with modification, applicable in forested peatlands. They should be used wherever possible because using the same protocols on peat and terra firme enables biomass, productivity, diversity, and other key vegetation 
parameters to be compared, which means that peatland vegetation can be understood in the broader context of tropical vegetation as a whole, and can be integrated into regional assessments of AGB across all ecosystems.

Modifications, or rather additions, to terra firme protocols for use on peatlands are necessary because 400 peatland vegetation is frequently dominated by plants that are usually regarded as negligible in a standard forest census, for example, thin-trunked trees with diameter at breast height (DBH) $<10 \mathrm{~cm}$ (the cut-off used in most AGB inventories), or grasses and sedges. An example of a modified protocol that remains compatible with standard RAINFOR protocols is provided by Roucoux et al. (2013) at Quistococha, Peru: a nested sampling design was used to record small trees with DBH between 2.5 and $10 \mathrm{~cm}$ in a series of sub-plots within their main census plot.

Another consideration is that peatland forests are often dominated by species (such as trunkless palms) to which standard allometric equations for calculating biomass do not apply (e.g. Chave et al. 2005; Feldpausch et al. 2011; Gehring et al. 2011). Outside Southeast Asia, the allometric equations used for AGB calculation of tropical peat swamp forests in recent literature (e.g. Kronseder et al. 2012; Englhart et al. 2013) were originally developed for "moist tropical forests" in general (Chave et al. 2005), and the performance of these models in the distinctive pole and palm forests often found on peatlands needs to be tested. Recently, species-specific equations have been developed for the most important peatland palms in South America including Mauritia flexuosa and Mauritiella armata (Goodman et al. 2013). Similar work remains to be carried out on many other species. The long history of economic exploitation of peat swamp forest in Southeast Asia means that allometric equations there are better established (Krisnawati et al. 2012).

New tools for assessing AGB on large spatial scales by remote sensing of canopy structure are rapidly developing (e.g. in Southeast Asian peatlands: Jubanski et al. 2013; Kronseder et al. 2012). Airborne LiDAR (Asner et al. 2013) and satellite-based LiDAR and L-band radar (e.g. Saatchi et al. 2011; Ballhorn et al. 2011; Mitchard et al. 2012; Baccini et al. 2012) have been widely used to estimate AGB, mainly in terra firme forests. As with mapping, more ground-reference data are needed to allow these approaches to be applied confidently to peatland forest AGB assessments (Table 1). 
Below-ground biomass (BGB: living roots, as opposed to the necromass or dead material contributing to peat) has hardly been studied in tropical peats, but existing research shows that root inputs can be more important to peat accumulation than leaf and stem litter, i.e. these are 'replacement peats' (Brady 1997; Chimner and Ewel 2005; Dommain et al. 2011). Measuring BGB is fraught with methodological problems even in terra firme forests, but it would be of great interest to know (in the context of understanding carbon balance and rates of carbon sequestration - see below) how much of the peat at various depths is made up of live or recently dead root material. However, for the purposes of estimating the size of carbon pools, the live and dead components of the peat do not need to be separated explicitly.

\section{Carbon fluxes}

In peatlands, carbon enters the peat in the form of litter and leaves it as dissolved organic carbon (DOC), particulate organic carbon (POC), and as the greenhouse gases $\mathrm{CH}_{4}$ and $\mathrm{CO}_{2}$. Comprehensive carbon flux measurements have been made for several well-studied northern peatlands (Roulet et al. 2007; Nilsson et al. 2008; Koehler et al. 2011), but a complete carbon budget has only been attempted once in tropical peat swamp forest (Chimner and Ewel 2005). The limited available data suggest that tropical peatland carbon sequestration rates are towards the upper end of the range for peatlands globally (Mitsch et al. 2010; Dommain et al. 2011; Glaser et al. 2012) due to a combination of high net primary production (NPP) and low decomposition rates (Dommain et al. 2011; Sjögersten et al. 2014).

The annual change in organic carbon for a peatland $\left(\Delta C_{\text {org }}\right)$ can be expressed as follows, following Roulet et al. (2007):

$$
\Delta C_{\text {org }}=N P P-F_{C_{2}}-F_{C H_{4}}-n e t D O C_{E X}-n e t P O C_{E X}
$$

where $\Delta C_{\text {org }}$ is equivalent net primary production (NPP) minus $F_{\mathrm{CO}_{2}}$ (the gaseous flux of $\mathrm{CO}_{2}$ ), $F_{\mathrm{CH}_{4}}$ (the gaseous flux of $\mathrm{CH}_{4}$ ), netDOC $C_{E X}$ (the waterborne DOC flux), and netPOC $C_{E X}$ (the waterborne POC flux). 
None of the quantities on the right hand side of equation 2 are easy to measure in any peatland, but in the tropics, NPP is especially difficult to quantify due to the large size of the plants on forested peatlands. The carbon flux can perhaps more easily be estimated using (i) the observed change in peat surface height, caused by accumulation and/or subsidence, relative to a fixed stake (e.g. Nagano et al. 2013; Couwenberg and Hooijer 2013); (ii) dating the basal peat to establish the apparent long term rate of carbon accumulation (LORCA: Clymo et al. 1998; Turunen et al. 2002; 'long term' in this context means centuries to millennia) as a direct measure of carbon sequestration over a given period of time (although this can differ substantially from present rates of carbon accumulation: Joosten and Clarke 2002:34); or (iii) measured rates of litter production and carbon losses through decomposition

(Chimner and Ewel 2005). Our discussion below focuses on the prospects for the direct measurement of litter input and decomposition, greenhouse gas fluxes (chiefly $\mathrm{CO}_{2}$ and $\mathrm{CH}_{4}$ ), and waterborne carbon fluxes, all of which are needed both to quantify the carbon flux in tropical peatlands and in order to develop a fuller mechanistic understanding of the controls on their carbon balance and greenhouse gas fluxes.

\section{Litter inputs}

The transformation of different types of litter in tropical forested peatlands - roots, non-woody leaf and stem litter, and woody debris ranging from twigs and small branches to whole tree trunks - into peat is poorly understood (Tie and Esterle 1992; Brady 1997; Sulistiyanto 2004; Chimner and Ewel 2005; Shimamura and Momose 2005). The quantity of litter inputs and the rate at which each litter type decomposes determine their contribution to the peat carbon pool. Leaves can comprise the bulk of above-ground litterfall in peat swamp forests (Sulistiyanto 2004) but they typically decompose much more rapidly than woody debris and roots and therefore contribute little to the overall accumulation of peat (Chimner and Ewel 2005), except perhaps where leaves accumulate in ponds on the peat surface (Gastaldo and Staub 1999).

Above-ground litterfall can be collected and weighed using nets of e.g. $1 \times 1 \mathrm{~m}$, depending on the size of the litter, although the logistics of the necessarily frequent sampling (due to high litter decomposition rates in the traps) can be restrictive. Suitable protocols have been developed by the CTFS Global Forest 
Carbon Research Initiative (www.ctfs.si.edu) and Harrison (2013); comparable sampling schemes have also been used in lowland tropical rainforest (Chambers et al. 2000; Nepstad et al. 2002). The contribution of large woody debris is harder to measure, and is almost unexplored in tropical peatlands. The frequency and relative importance of branch- and tree-fall events can be estimated by repeated litter surveys along transects (Waddell 2002) or in census plots (Chimner and Ewel 2005; Woodall and Monleon 2008; Baker and Chao 2011), although no standard method has yet been agreed upon (Larjavaara and Muller-Landau 2011); further methodological research is needed.

Equally, very few data on root dynamics are available for tropical peatlands. Root growth, especially of fine roots, can be measured using the ingrowth core or bag method (e.g. Symbula and Day 1988; Neill 1992; Brady 1997; Finér and Laine 1998; Metcalfe et al. 2008), though this can be problematic: important considerations are the linearity of root growth over the study period and temporal variation in root production, e.g. between dry and wet seasons (Metcalfe et al. 2008), as well as changes in soil structure caused by the removal of roots from the soils during preparation of the ingrowth core, which may affect later root growth. Root mortality (i.e. root litter input to the necromass) is extremely difficult to determine and involves differentiating between live and dead root material (Finér and Laine 1998). Alternative approaches, such as the use of minirhizotrons which allow in situ measurements of root growth and mortality (Iversen et al. 2012), have been used successfully in lowland tropical rainforest (Metcalfe et al. 2007) but not yet in tropical peatlands.

\section{Litter decomposition}

Potential in situ litter decomposition rates in tropical peatlands appear higher than in temperate/boreal peatlands (Brady 1997; Chimner and Ewel 2005; Yule and Gomez 2008), presumably due mainly to the year-round higher ambient temperatures, although other factors including litter composition, water table depth, and pH may also be involved (Qualls and Haines 1990; Chimner and Ewel 2005; Yule and Gomez 2008). Few systematic studies have been carried out, especially outside Southeast Asia.

Standard techniques for measuring the decomposition rate of fine litter are readily applied in tropical 
peatlands, in which rapid decomposition allows meaningful results to be obtained over sampling periods as short as two years (Yule and Gomez, 2008; Hoyos 2014). Mesh bags containing known dry weights of litter are firmly anchored to the ground to prevent them being washed away during floods, or are buried in the peat and collected at regular intervals to calculate weight loss (Chimner and Ewel 2005; Wright et al. 2013a; Hoyos 2014). Decomposition of large woody debris such as fallen trees or large branches is also presumably important in forested peatlands, but sampling is more difficult, usually requiring repeated surveys over long intervals, and data are lacking. One approach would be to follow (or build on) RAINFOR protocols to establish permanent forest census plots, which include a protocol for measuring coarse woody debris (Baker and Chao 2011). Census plots that are part of a network such as RAINFOR, where the data are relevant to many research questions, are more likely than not to be revisited over many years and hence to generate the necessary long-term datasets.

\section{Greenhouse gas fluxes}

To date, most data on GHG fluxes from tropical peatlands have been collected during daylight hours using static sampling chambers placed on the peat surface (Jauhiainen et al. 2005, 2008, 2012; Melling et al. 2005a, b; Sjögersten et al. 2011; Wright et al. 2011, 2013b). Automated sampling has not yet been widely adopted but is becoming more common (Sundari et al. 2012; Hirano et al. 2014). Measured GHG fluxes from peat swamp forests vary greatly both across the tropics (Sjögersten et al. 2014) and within sites (Wright et al. 2013b), often correlating with mean annual water table depth (Couwenberg et al. 2010).

Substantial temporal variation (diurnal and seasonal) poses a major challenge to obtaining reliable estimates of GHG emissions. Current data suggest that temporal variation exceeds the spatial variation between forest types (Wright et al. 2013b), and that there is frequently a strong correlation between GHG efflux and temporal variation in water table depth (Jauhiainen et al. 2005; Hirano et al. 2009, 2014; Sundari et al. 2012). Long-term data (e.g. over more than a year) obtained at regular (e.g. monthly) intervals are scarce, so the magnitude of intra- and inter-annual variation in fluxes is unclear. Strong diurnal variation in $\mathrm{CO}_{2}$ and $\mathrm{CH}_{4}$ efflux (e.g. Hirano et al, 2009; Wright et al. 2013b; Hoyos 2014) means that measurements intended for estimating net GHG fluxes need to include 
measurements at 2-4 hourly intervals or better. The effect of weather (e.g. rainfall events) and seasonality (e.g. dry/wet season contrasts) on GHG emissions, and the importance of ebullition in methane emission, also remain to be thoroughly investigated. Automated samplers capable of frequent (sub-hourly) measurements over long periods (many months; e.g. Goodrich et al. 2011) can help to resolve these issues.

Alternatively, the eddy-flux correlation approach can be used to acquire gas flux data with high temporal resolution, spatially integrated over hundreds of metres. Eddy-flux systems are currently under-used in tropical peatlands, with data presently only available from sites in Narathiwat Province, Thailand (Suzuki et al. 1999) and Kalimantan, Indonesia (Hirano et al. 2009, 2012). Additional systems will shortly become operational in Brunei, Sarawak (Malaysia), and Peru.

Additional uncertainty in estimates of peat decay rate arise because most $\mathrm{CO}_{2}$ flux data from tropical peatlands do not separate autotrophic (from roots) and heterotrophic respiration (from decomposing peat) which makes it difficult to use peat surface measurements of GHGs to assess peat decay rates (Page et al. 2011a). In plantations with regularly spaced trees and little ground cover, attempts have been made to distinguish between soil and root respiration by measuring $\mathrm{CO}_{2}$ release within and between rows of trees (Jauhiainen et al. 2012). Alternative approaches to separating autotrophic and heterotrophic respiration are (i) to compare the $\mathrm{CO}_{2}$ release from buried mesh collars which restrict in-growth of roots, with collars which allow roots to grow in (Nottingham et al. 2011), or (ii) using a trenching approach (Mäkiränta et al. 2008), which involves isolating a patch of ground from root influences by cutting/digging through the roots around the plot (Mäkiränta et al. 2008), although this may affect the peat moisture status in trenched plots, with implications for $\mathrm{CO}_{2}$ fluxes.

A further uncertainty regarding net GHG emissions is related to the pathway for $\mathrm{CH}_{4}$ emissions through tree stems, which a study by Pangala et al. (2013) at a peatland in Borneo found to account for a very large proportion (62-87\%) of ecosystem $\mathrm{CH}_{4}$ emissions. The extent to which this pathway is generally important needs to be established by comparable studies at other sites. 
553 Waterborne carbon fluxes (DOC and POC) from tropical peatlands represent a major source of 554 uncertainty in their overall carbon balance. In temperate peatlands, waterborne carbon typically 555 accounts for c. 10\% of total carbon export (Limpens et al. 2008). In the few studies in which DOC and POC fluxes from tropical peatlands (all in Southeast Asia) have been measured (Yoshioka et al. 2002; Baum et al. 2007), they have been found to be approximately double those from temperate peatlands (IPCC 2014). Moore et al. (2011) estimated that the peat-covered part of Indonesia alone was responsible for $10 \%$ of global fluvial DOC export to the ocean. Waterborne fluxes may be especially significant in degraded peatlands where the forest vegetation has been removed and the peat has destabilised (cf. Moore et al. 2013), and in floodplain peatlands where fluvial erosion can remove large blocks of peat en masse during floods. Further quantification of these processes is needed.

Total export of waterborne carbon can most easily be estimated for peatlands which have a clear hydrological boundary and discrete outflows, by measuring DOC and POC concentrations in drainage streams regularly during annual or longer periods, along with the total water discharge (Billett et al. 2004; Moore et al. 2011, 2013). The achievable temporal resolution of measurements is a critical limitation. Woody tropical peats often have high saturated hydraulic conductivity in their near-surface layers, but below-ground flow is frequently insufficient to shed the large and sporadic inputs from rainfall (Kelly et al. 2013); evapotranspiration and, especially in the wet season, surface runoff play a large role in the hydrological budget. The pathway taken by water as it leaves a peatland affects its DOC and POC load. Water which is shed rapidly through surface runoff may have a low DOC concentration due to its shorter residence time, but equally, especially in degraded peatlands, rapid runoff may cause peatland erosion and carry a greater POC load. In such hydrologically dynamic peatlands, discreet pulses of DOC and POC losses may be missed unless monitoring is carried out very frequently. In a recent study, Moore et al. (2013) focused sampling effort on the peak of the dry season and wet season, taking measurements every week during these periods. For the rest of the year, they took samples every fortnight. We recommend this as a minimum sampling resolution for future studies, taking into account the difficulty of regular sampling in many tropical peatlands; where 
sampling can be undertaken more intensively (for example, using automated samplers) then this should be attempted. Further research on tropical peatland hydrology (e.g. Kelly et al. 2014) leading to more reliable hydrological models would also help in estimating waterborne carbon fluxes.

\section{Conclusions}

Tropical peatland research with a focus on their role as carbon stores, sinks and sources is becoming an increasingly active field, and an important one in relation to management of the global carbon cycle. In this review we have identified many research needs, including methodological problems, and have suggested some approaches to tackling them. In our view, however, the overarching need is for a more coordinated approach to data collection and sharing. This is necessary to allow us to address the most fundamental, large-scale questions about how much peat exists in the tropics, and where it is; and about the role of tropical peatlands in the global carbon cycle, today and in the future. Our main conclusions and recommendations are as follows:

1. Tropical peatland research would benefit from a network of sites where basic measurements have been made using identical methodologies. A precedent exists in the well-organised, extensive networks of permanent tropical forest census plots (e.g. RAINFOR and AFRITRON). Where practical, methods should be compatible with those used for peatland research outside the tropics, but perhaps more importantly, they should be compatible with methods used in other tropical ecosystems (particularly terra firme forest), in recognition of the fact that effective management depends primarily on being able to compare the relative costs and benefits of managing peatlands and other ecosystems in the same region for carbon storage and other ecosystem services. Table 1 proposes a set of measurements which are cheap and practical to implement as part of basic site description, and which would help to build a pan-tropical dataset that would put regional and global estimates of tropical peatland carbon stocks and fluxes on a firmer footing.

2. Concerted effort to focus research on particular sites, drawing on both the social and the natural sciences, has proven successful at one tropical peatland (Allen et al. 2005; Chimner and Ewel, 2005; Drew et al. 2005). We would like to see the research community continue to build on this collaborative 
and interdisciplinary approach by establishing a small number of keystone sites where a rich body of knowledge can be accumulated over time. This would facilitate the testing of conceptual and numerical models of peatland processes, and would help to build long-term datasets that can be used to analyse temporal variability in peatland behaviour.

3. As in many other fields, it would be helpful if data were routinely published in full, in tabular form in papers (as supplementary data if necessary) or in appropriate data repositories such as the Carbon Dioxide Information Analysis Center (http://cdiac.ornl.gov/) or the UK Environmental Information Data Centre (http://www.ceh.ac.uk/data), in order to facilitate reanalysis and synthesis. Full publication of data is increasingly required by grant funding bodies. The fact that this so rarely happens at present suggests that mechanisms are needed to incentivise sharing of data between researchers. Again, existing networks such as RAINFOR (Malhi et al. 2002) offer precedents to follow, in terms of 'ground rules' that incentivise data sharing by guaranteeing opportunities for coauthorship of any publications that result.

4. There is, separately, a need for a community-wide data synthesis project to build a GIS-compatible database on carbon storage in tropical peatlands (and indeed, peatlands globally) that would facilitate inter-site comparisons.

5. Throughout this review we have identified research priorities which, if addressed, would improve our ability to make reliable measurements and to extrapolate from point measurements to regional and global assessments of peatland carbon stocks and fluxes. These include:

a. Studying the relationships between peat properties, the overlying vegetation, and their remote sensing signatures;

b. Developing radar/LiDAR techniques for mapping tropical peatlands and measuring AGB;

c. Investigating the use of multiple remote sensing methods in combination in mapping tropical peatlands;

d. Collaboratively developing large ground reference point datasets to support remote sensing;

e. Investigating further the potential for inferring peat thickness by GPR and remote sensing; 
f. Systematically comparing different volumetric peat sampling methods;

g. Investigating the spatial and stratigraphic variation in peat DBD and carbon concentration;

h. Investigating the relative importance of different litter inputs (including coarse woody debris and roots) to peat formation/C flux;

i. Improving our understanding of the spatial and, especially, temporal variation in greenhouse gas fluxes from peatlands;

j. Investigating further the importance of vegetation (especially trees) as conduits for greenhouse gases in tropical peatlands.

\section{Acknowledgments}

We would like to thank A.J. Baird and G.T. Swindles for comments on an earlier version of the text, and the two anonymous reviewers for insightful comments that greatly improved this article. The workshops that led to this article were supported financially by the Universities of Leicester and Nottingham, and the Natural Environment Research Council-funded 'Earth Observation Technology Cluster' knowledge exchange initiative.

\section{References}

Allen JA, Krauss KW, Ewel KC, Keeland BD, Waguk EE (2005) A tropical freshwater wetland: 1. Structure, growth, and regeneration. Wetl Ecol Manag 13:657-669

Alsdorf DE (2003) Water storage of the central Amazon floodplain measured with GIS and remote sensing imagery. Ann Assoc Am Geogr 93:55-66

Anderson JAR (1983) The tropical peat swamps of western Malesia. In: Gore AJP (ed) Ecosystems of the World 4B: Mires: Swamp, Bog, Fen and Moor. Elsevier, Amsterdam, New York, pp 181-199

Asner GP, Mascaro J, Anderson C, Knapp DE, Martin RE, Kennedy-Bowdoin T, van Breugel M, Davies S, Hall JS, Muller-Landau HC, Potvin C, Sousa W, Wright J, Bermingham E (2013) High-fidelity national carbon mapping for resource management and REDD+. Carbon Balance Manage 8:1-7 
Baccini A, Goetz SJ, Walker WS, Laporte NT, Sun M, Sulla-Menashe D, Hackler J, Beck PSA, Dubayah R, Friedl MA, Samanta S, Houghton RA (2012) Estimated carbon dioxide emissions from tropical deforestation improved by carbon-density maps. Nature Clim Change 2:182-185

Baker TR, Phillips OL, Malhi Y, Almeida S, Arroyo L, Di Fiore A, Martínez RV (2004) Increasing biomass in Amazonian forest plots. Philos T R Soc B 359:353-365

Baker TR, Chao KJ (2011) Manual for Coarse Woody Debris Measurement in RAINFOR Plots. http://www.rainfor.org/upload/ManualsEnglish/CWD_protocol_RAINFOR_2011_EN.pdf

Ballhorn U, Siegert F, Mason M, Limin S (2009) Derivation of burn scar depths and estimation of carbon emissions with LIDAR in Indonesian peatlands. P Natl A Acad Sci USA 106:21213-21218

Ballhorn U, Jubanski J, Siegert F (2011) ICESat/GLAS data as a measurement tool for peatland topography and peat swamp forest biomass in Kalimantan, Indonesia. Remote Sensing 3:1957-1982

Baum A, Rixen T, Samiaji J (2007) Relevance of peat draining rivers in central Sumatra for the riverine input of dissolved organic carbon into the ocean. Estuar Coast Shelf S 73:563-570

Betbeder J, Gond V, Frappart F, Baghdadi NN, Briant G, Bartholome E (2014) Mapping of Central Africa forested wetlands using remote sensing. IEEE J Sel Top Appl 7:2014 531-542

Billett MF, Palmer SM, Hope D, Deacon C, Storeton-West R, Hargreaves KJ, Flechard C, Fowler D (2004) Linking land-atmosphere-stream carbon fluxes in a lowland peatland system. Global Biogeochem Cy 18:GB1024

Brady MA (1997) Organic Matter Dynamics of Coastal Peat Deposits in Sumatra, Indonesia. Unpublished PhD thesis, University of British Columbia.

Buringh P (1984) Organic carbon in soils of the world. In: Woodwell GM (ed.) The Role of Terrestrial Vegetation in the Global Carbon Cycle: Measurement by Remote Sensing, pp. 91-109. Chichester: John Wiley \& Sons.

Bwangoy J-RB, Hansen MC, Roy DP, De Grandi G, Justice CO (2010) Wetland mapping in the Congo 
Basin using optical and radar remotely sensed data and derived topographical indices. Remote Sens Environ 114:73-86

Campbell D (2005) The Congo River basin. In: Fraser LH, Keddy PA (eds), The World's Largest Wetlands: Ecology and Conservation. Cambridge: Cambridge University Press, 149-165

Chambers FM, Beilman DW, Yu Z (2011) Methods for determining peat humification and for quantifying peat bulk density, organic matter and carbon content for palaeostudies of climate and peatland carbon dynamics. Mires and Peat 7, Art. 7. http://www.mires-andpeat.net/pages/volumes/map07/map0707.php1-10

Chambers JQ, Higuchi N, Ferreira LV, Melack JM, Schimel JP (2000) Decomposition and carbon cycling of dead trees in tropical forests of the Central Amazon. Oecologia 122:380-388

Chave J, Andalo J, Brown S, Cairns MA, Chambers JQ, Eamus D, Fölster H, Fromard F, Higuchi N, Kira T, Lescure J-P, Nelson BW, Ogawa H, Puig H, Riéra B, Yamakura T (2005) Tree allometry and improved estimation of carbon stocks and balance in tropical forests. Oecologia 145:87-99

Chimner RA, Ewel KC (2005) A tropical freshwater wetland: II. Production, decomposition, and peat formation. Wetl Ecol Manag 13:671-684

Chimner RA, Ott CA, Perry CH, Kolka RK (2014) Developing and evaluating rapid field methods to estimate peat carbon. Wetlands. doi: 10.1007/s13157-014-0574-6

Clymo RS (1983) Peat. In: Gore AJP (ed) Ecosystems of the World, vol. 4A, Mires: Swamp, Bog, Fen and Moor, pp. 159-224. Amsterdam/New York: Elsevier.

Clymo RS, Turunen J, Tolonen K (1998) Carbon accumulation in peatland. Oikos 81:368-388.

Couwenberg J, Dommain R, Joosten H (2010) Greenhouse gas fluxes from tropical peatlands in southeast Asia. Glob Change Biol 16:1715-1732

Couwenberg J, Hooijer A (2013) Towards robust subsidence-based soil carbon emission factors for peat soils in south-east Asia, with special reference to oil palm plantations. Mires and Peat 12 Art. 1. 
704 Cubizolle H, Mouandza MM, Muller F (2013) Mires and histosols in French Guiana (South America): 705 new data relating to location and area. Mires and Peat 12: Art. 3. http://www.mires-and706 peat.net/pages/volumes/map12/map1203.php

de Grandi GF, Mayaux P, Rauste Y, Rosenqvist A, Saatchi S, Simard M, Leysen M (1998) Flooded forest mapping at regional scale in the Central Africa Congo River Basin: first thematic results derived by ERS-1 and JERS-1 radar mosaics. In: Proceedings of the Second International Workshop on Retrieval of Bio- and Geophysical Parameters from SAR Data, October 21-23, 1998. Noordwijk, The Netherlands: ESA Publications, 253-260

de Grandi GF, Mayaux P, Malingreau JP, Rosenqvist A, Saatchi S, Simard M (2000) New perspectives on global ecosystems from wide-area radar mosaics: flooded forest mapping in the tropics. Int J Remote Sens 21:1235-1249

De Vleeschouwer F, Chambers FM, Swindles GT (2010) Coring and sub-sampling of peatlands for palaeoenvironmental research. Mires and Peat 7: Art. 1. http://www.mires-andpeat.net/pages/volumes/map07/map0701.php

Dommain R, Couwenberg J, Joosten H (2011) Development and carbon sequestration of tropical peat domes in south-east Asia: links to post-glacial sea-level changes and Holocene climate variability. Quaternary Sci Rev 30:999-1010

Dommain R, Couwenberg J, Glaser PH, Joosten H, Nyoman I, Suryadiputra N (2014) Carbon storage and release in Indonesian peatlands since the last deglaciation. Quaternary Sci Rev 97:1-32

Draper FC, Roucoux KH, Lawson IT, Mitchard ETA, Honorio Coronado EN, Lähteenoja O, Torres Montenegro L, Valderrama E, Zaráte R, Baker TR (in press) Distribution and carbon stock of West Amazonian peatlands. Env Res Lett and other goods and services. Wetl Ecol Manag 13:685-693. 
Englhart S, Jubanski J, Siegert F (2013) Quantifying Dynamics in Tropical Peat Swamp Forest Biomass with Multi-Temporal LiDAR Datasets. Remote Sens 5:2368-2388

Farmer J, Matthews R, Smith P, Langan C, Hergoualc'h K, Verchot L, Smith JU (2013) Comparison of methods for quantifying soil carbon in tropical peats. Geoderma. doi: 10.1016/j.geoderma.2013.09.013

Feldpausch TR, Banin L, Phillips OL, Baker TR, Lewis SL, Quesada CA, Affum-Baffoe K, Arets EJMM, Berry NJ, Bird M, Brondizio ES, de Camargo P, Chave J, Djagbletey G, Domingues TF, Drescher M, Fearnside PM, França MB, Fyllas NM, Lopez-Gonzalez G, Hladik A, Higuchi N, Hunter MO, Iida Y, Salim KA, Kassim AR, Keller M, Kemp J, King DA, Lovett JC, Marimon BS, Marimon-Junior BH, Lenza E, Marshall AR, Metcalfe DJ, Mitchard ETA, Moran EF, Nelson BW, Nilus R, Nogueira EM, Palace M, Patiño S, Peh KS-H, Raventos MT, Reitsma JM, Saiz G, Schrodt F, Sonké B, Taedoumg HE, Tan S, White L, Wöll H, Lloyd J (2011) Height-diameter allometry of tropical forest trees. Biogeosciences 8:1081-1106

Finér L, Laine J (1998) Root dynamics at drained peatland sites of different fertility in southern Finland. Plant Soil 201:27-36

Franke J, Navratil P, Keuck V, Peterson K, Siegert F (2012) Monitoring fire and selective logging activities in tropical peat swamp forests. IEEE J Sel Top Appl 5:1811-1820

Gallego-Sala AV, Prentice IC (2012) Blanket peat biome endangered by climate change. Nature Clim Change 3:152-155

Gastaldo RA, Staub JR (1999) A mechanism to explain the preservation of leaf litter lenses in coals derived from raised mires. Palaeogeogr Palaeocl 149:1-14

Gehring C, Zelarayán ML, Almeida RB, Moraes FHR (2011) Allometry of the babassu palm growing on a slash-and-burn agroecosystem of the eastern periphery of Amazonia. Acta Amazonica 41:127-134

Givelet N, Le Roux G, Cheburkin A, Chen B, Frank J, Goodsite ME, Kempter H, Krachler M, Noernberg T, Rausch N, Rheinberger S, Roos-Barraclough F, Sapkota A, Scholz C, Shotyk W (2004) Suggested protocol for collecting, handling and preparing peat cores and peat samples for physical, chemical, 
Glaser PH, Volin JC, Givnish TJ, Hansen BCS, Stricker CA (2012) Carbon and sediment accumulation in the Everglades (USA) during the past 4000 years: rates, drivers, and sources of error. J Geophys Res 756 117:GB3026 (2013) Amazon palm biomass and allometry. Forest Ecol Manag 310:994-1004

Goodrich JP, Varner RK, Frolking S, Duncan BN, Crill PM (2011) High-frequency measurements of methane ebullition over a growing season at a temperate peatland site. Geophys Res Lett 38:L07404.

761 Gorham E (1991) Northern peatlands: role in the carbon cycle and probable responses to climatic warming. Ecol Appl 1:182-195

Harrison ME (2013) Standard Operating Procedure: Forest Litter-fall. Orangutan Tropical Peatland Project, Palangka Raya, Indonesia. http://www.outrop.com/uploads/7/2/4/9/7249041/litterfall.pdf

Heiri O, Lotter AF, Lemcke G (2001) Loss on ignition as a method for estimating organic and carbonate content in sediments: reproducibility and comparability of results. J Paleolimnol 25:101-110 inundation and vegetation for the central Amazon basin. Remote Sens Environ 87:404-428

Hirano T, Jauhiainen J, Inoue T, Takahashi H (2009) Controls on the carbon balance of tropical peatlands. Ecosystems 12:873-887

771 Hirano T, Segah H, Kusin K, Limin S, Takahashi H, Osaki M (2012) Effects of disturbances on the carbon 772 balance of tropical peat swamp forests. Global Change Biol 18:3410-3422

773 Hirano T, Kusin K, Limin S, Osaki M (2014) Carbon dioxide emissions through oxidative peat decomposition on a burnt tropical peatland. Global Change Biol 20:555-565 
Hoekman D, Vissers M (2007) ALOS PALSAR radar observation of tropical peat swamp forest as a monitoring tool for environmental protection and restoration. Proc IEEE Int Geosci Remote Sens Symp $3710-3714$

Hooijer A, Page SE, Jauhiainen J, Lee WA, Lu XX, Idris A, Anshari G (2012) Subsidence and carbon loss in drained tropical peatlands. Biogeosciences 9:1053-1071

Householder JE, Janovec JP, Tobler MW, Page SE, Lähteenoja O (2012) Peatlands of the Madre de Dios River of Peru: distribution, geomorphology, and habitat diversity. Wetlands 32:359-368

Hoyos J (2014) Controls of Carbon Turnover in Tropical Peatlands. Unpublished PhD thesis, University of Nottingham

IPCC (2014) Supplement to the 2006 IPCC Guidelines for National Greenhouse Gas Inventories: Wetlands (eds Hiraishi T, Krug T, Tanabe K, Srivastava N, Baasansuren J, Fukuda M, Troxler TG). Switzerland: IPCC.

Iversen CM, Murphy MT, Allen MF, Childs J, Eissenstat DM, Lilleskov EA, Sarjala TM, Sloan VL, Sullivan PF (2012) Advancing the use of minirhizotrons in wetlands. Plant Soil 352:23-39

Jaenicke J, Rieley JO, Mott C, Kimman P, and Siegert F (2008) Determination of the amount of carbon stored in Indonesian peatlands. Geoderma 147:51-158

Jaenicke J, Wosten H, Budiman A, and Siegert F (2010) Planning hydrological restoration of peatlands in Indonesia to mitigate carbon dioxide emissions. Mitig Adapt Strategies Glob Chang 15:223-239

Jauhiainen J, Hooijer A, Page SE (2012) Carbon dioxide emissions from an Acacia plantation on peatland in Sumatra, Indonesia. Biogeosciences 9:617-630

Jauhiainen J, Limin S, Silvennoinen H, Vasander H (2008) Carbon dioxide and methane fluxes in drained tropical peat before and after hydrological restoration. Ecology 89:3503-3514

Jauhiainen J, Takahashi H, Heikkinen JEP, Martikainen PJ, Vasander H (2005) Carbon fluxes from a tropical peat swamp forest floor. Global Change Biol 11:1788-1797 
801 802 803 804 805 806 807 808 809 810 811

Joosten H, Clarke D (2002) Wise Use of Mires and Peatlands - Background and Principles Including a Framework for Decision-Making. International Mire Conservation Group/International Peat Society.

Joosten H, Tapio-Biström M-L, Tol S (eds, 2012) Peatlands - Guidance for Climate Change Mitigation Through Conservation, Rehabilitation and Sustainable Use (2nd edition). Food and Agriculture Organization of the United Nations/Wetlands International, Rome.

Jubanski J, Ballhorn U, Kronseder K, Franke J, Siegert F (2013) Detection of large above ground biomass variability in lowland forest ecosystems by airborne LIDAR. Biogeosciences 10:3917-3930

Jung HC, Hamski J, Durand M, Alsdorf D, Hossain F, Lee H, Hussain AKMA, Hasan K, Khan AS, Hoque AKMZ (2010) Characterization of complex fluvial systems using remote sensing of spatial and temporal water level variations in the Amazon, Congo, and Brahmaputra Rivers. Earth Surf Proc Land $35: 294-304$

Keddy PA, Fraser LH, Solomeshch AI, Junk WJ, Campbell DR, Arroyo MTK, Alho CJR (2009) Wet and wonderful: the world's largest wetlands are conservation priorities. Bioscience 59:39-51

Kelly TJ, Baird AJ, Roucoux KH, Baker TR, Honorio Coronado EN, Ríos M, Lawson IT (2013) The high hydraulic conductivity of three wooded tropical peat swamps in northeast Peru: measurements and implications for hydrological function. Hydrol Process 28:3373-3387

Koehler, AK, Sottocornola M, Kiely G (2011) How strong is the current carbon sequestration of an Atlantic blanket bog? Global Change Biol 17:309-319

Krisnawati H, Catur Adinugroho W, Imanuddin R (2012) Monograph: Allometric Models for Estimating Tree Biomass at Various Forest Ecosystem Types in Indonesia. Research and Development Center for Conservation and Rehabilitation, Forestry Research and Development Agency, Bogor, Indonesia.

Kronseder K, Ballhorn U, Böhm V, Siegert F (2012) Above ground biomass estimation across forest types at different degradation levels in Central Kalimantan using LIDAR data. Int J App Earth Obs $18: 37-48$

Lähteenoja O, Page S (2011) High diversity of tropical peatland ecosystem types in the 
Lähteenoja O, Ruokolainen K, Schulman L, Oinonen M (2009a) Amazonian peatlands: an ignored C sink and potential source. Global Change Biol 15:2311-2320

Lähteenoja O, Ruokolainen K, Schulman L, Alvarez J (2009b) Amazonian floodplains harbour minerotrophic and ombrotrophic peatlands. Catena 79:140-145

Lähteenoja 0, Rojas Reátegui Y, Räsänen M, Del Castillo Torres D, Oinonen M, Page, SE (2012) The large Amazonian peatland carbon sink in the subsiding Pastaza-Marañón foreland basin, Peru. Global Change Biol 18:164-178

Lähteenoja O, Flores B, Nelson B (2013) Tropical Peat Accumulation in Central Amazonia. Wetlands $33: 495-503$

Langner A, Miettinen J, Siegert F (2007) Land cover change 2002-2005 in Borneo and the role of fire derived from MODIS imagery. Global Change Biol 13:2329-2340

Larjavaara M, Muller-Landau HC (2011) Cross-section mass: An improved basis for woody debris necromass inventory. Silva Fenn 45:291-298

Lawson IT, Jones TD, Kelly TJ, Honorio Coronado EN, Roucoux KH (2014) The Geochemistry of Amazonian peats. Wetlands. doi: 10.1007/s13157-014-0552-z

Lee G (2000) An analysis of human impact on humid, tropical forests in Jambi, Indonesia using satellite images. Proceedings IGARSS 2000 I-VI, 1963-1965

Lee H, Beighley RE, Alsdorf D, Jung HC, Shum CK, Duan J, Guo J, Yamazaki D, Andreadis K (2011) Characterization of terrestrial water dynamics in the Congo Basin using GRACE and satellite radar altimetry. Remote Sens Environ 115:3530-3538

Letcher SG, Chazdon RL (2009) Rapid recovery of biomass, species richness, and species composition in a forest chronosequence in northeastern Costa Rica. Biotropica 41:608-617

Lewis SL, Brando PM, Phillips OL, van der Heijden GM, Nepstad D (2011) The 2010 amazon drought. 
851 Li H, Mausel P, Brondizio E, Deardorff D (2010) A framework for creating and validating a non-linear 852 spectrum-biomass model to estimate the secondary succession biomass in moist tropical forests. 853 ISPRS J Photogramm 65:241-254

854 Limpens J, Berendse F, Blodau C, Canadell JG, Freeman C, Holden J, Roulet N, Rydin H, Schaepman855 Strub G (2008) Peatlands and the carbon cycle: from local processes to global implications - a 856 synthesis. Biogeosciences Discuss 5:1379-1419

Malhi Y, Phillips OL. Lloyd J, Baker T, Wright J, Almeida S, Arroyo L, Frederiksen T, Grace J, Higuchi N, 858

Killeen T, Laurance W, Leaño C, Lewis S, Meir P, Monteagudo A, Neill D, Núñez Vargas P, Panfil SN,

Patiño SN, Pitman N, Quesada CA, Rudas A-Ll., Salomão R, Saleska S, Silva N, Silveira M, Sombroek WG,

Valencia R, Vásquez Martínez R, Vieira ICG, Vinceti B (2002) An international network to monitor the structure, composition and dynamics of Amazonian forests (RAINFOR). J Veg Sci 13:439-450

Mäkiränta P, Minkkinen K, Hytönen J, Laine J (2008) Factors causing temporal and spatial variation in 863 heterotrophic and rhizospheric components of soil respiration in afforested organic soil croplands in

Finland. Soil Biol Biochem 40:1592-1600

865

Manly BFJ (2007) Randomization, Bootstrap and Monte Carlo methods in Biology. Boca Raton:

Chapman and Hall.

Melling L, Hatano R, Goh KJ (2005a) Soil $\mathrm{CO}_{2}$ flux from three ecosystems in tropical peatland of 868 Sarawak, Malaysia. Tellus 57B:1-11

Melling L, Hatano R, Goh KJ (2005b) Methane fluxes from three ecosystems in tropical peatland of Sarawak, Malaysia. Soil Biol Biochem 37:1445-1453

Metcalfe DB, Meir P, Aragão LEOC, Malhi Y, da Costa ACL, Braga A, Gonçalves PHL, de Athaydes J, de Almeida SS, Williams M (2007) Factors controlling spatio-temporal variation in carbon dioxide efflux 873 from surface litter, roots, and soil organic matter at four rain forest sites in the eastern Amazon. J 
Metcalfe DB, Meir P, Aragão LEO, da Costa ACL, Braga AP, Gonçalves PHL, de Athaydes Silva Jr J, de Almeida SS, Dawson LA, Mahli Y, Williams M (2008) The effects of water availability on root growth and morphology in an Amazon rainforest. Plant Soil 311:189-199

Miettinen J, Hooijer A, Shi C, Tollenaar D, Vernimmen R, Liew SC, Malins C, Page SE (2012) Extent of industrial plantations on Southeast Asian peatlands in 2010 with analysis of historical expansion and future projections. Glob Change Biol Bioenergy 4:908-918.

Miettinen J, Liew SC (2010) Degradation and development of peatlands in peninsular Malaysia and in the islands of Sumatra and Borneo since 1990. Land Degrad Dev 21:285-296

Mitchard ETA, Saatchi SS, White LJT, Abernethy KA, Jeffery KJ, Lewis SL, Collins M, Lefsky MA, Leal ME, Woodhouse IH, Meir P (2012) Mapping tropical forest biomass with radar and spaceborne LiDAR: overcoming problems of high biomass and persistent cloud. Biogeosciences 9:179-191

Mitsch WJ, Nahlik A, Wolski P, Bernal B, Zhang L, Ramberg L (2010) Tropical wetlands: seasonal hydrologic pulsing, carbon sequestration, and methane emissions. Wetl Ecol Manag 18:573-586

Moore S, Gauci V, Evans CD, Page SE (2011) Fluvial organic carbon losses from a Bornean blackwater river. Biogeosciences 8:901-909

Moore R, Evans CD, Page SE, Garnett MH, Jones TG, Freeman C, Hooijer A, Wiltshire AJ, Limin SH, Gauci V (2013) Deep instability of deforested tropical peatlands revealed by fluvial organic carbon fluxes. Nature 493:660-663

Murdiyarso D, Hergoualc'h K, Verchot LV (2010) Opportunities for reducing greenhouse gas emissions in tropical peatlands. P Natl A Acad Sci USA 107:19655-19660

Nagano T, Osawa K, Ishida T, Sakai K, Vijarnsorn P, Jongskul A, Phetsuk S, Waijaroen S, Yamanoshita T, Norisada M, Kojima K (2013) Subsidence and soil $\mathrm{CO}_{2}$ efflux in tropical peatland in southern Thailand under various water table and management conditions. Mires and Peat 11: Art. 6 http://www.miresand-peat.net/pages/volumes/map11/map1106.php. 
production. Ecology 73:1918-1921

Nelson DW, Sommers LE, Sparks DL, Page AL, Helmke PA, Loeppert RH, Soltanpour PN, Tabatabai MA, Johnston CT, Sumner ME (1996) Total carbon, organic carbon, and organic matter. In: Sparks DL (ed.) Methods of Soil Analysis. Part 3-Chemical Methods. Madison, Wisconsin: Soil Science Society of America/American Society of Agronomy, 961-1010

Nepstad DC, Moutinho P, Dias-Filho MB, Davidson E, Cardinot G, Markewitz D, Figueiredo R, Vianna N, Chambers J, Ray D, Guerreiros JB, Lefebvre P, Sternberg L, Moreira M, Barros L, Ishida FY, Tohlver I, Belk E, Kalif K, Schwalbe K (2002) The effects of partial throughfall exclusion on canopy processes, aboveground production, and biogeochemistry of an Amazon forest. J Geophys Res-Atmos 107(D20):8085

Nilsson M, Sagerfors J, Buffam I, Laudon H, Eriksson T, Grelle A, Klemedtsson L, Weslien P, Lindroth A (2008) Contemporary carbon accumulation in a boreal oligotrophic minerogenic mire - a significant sink after accounting for all C-fluxes. Global Change Biol 14:2317-2332

Nottingham AT, Turner BL, Winter K, van der Heijden MGA, Tanner EVJ (2011) Arbuscular mycorrhizal mycelial respiration in a moist tropical forest. New Phytol 186:957-967

Page SE, Morrison R, Malins C, Hooijer A, Rieley JO, Jauhianen J (2011a) Review of peat surface greenhouse gas emissions from oil palm plantations in Southeast Asia. Washington DC: White Paper No. 15, International Committee on Clean Transportation (ICTT), 76pp.

Page SE, Rieley JO, Shotyk ØW, Weiss D (1999) Interdependence of peat and vegetation in a tropical peat swamp forest. Philos T R Soc B 354:1885-1897

Page SE, Seigert F, Rieley JO, Boehm H-DV, Jaya A, Limin S (2002) The amount of carbon released from peat and forest fires in Indonesia during 1997. Nature 420:61-65

Page SE, Rieley JO, Banks CJ (2011b) Global and regional importance of the tropical peatland carbon pool. Global Change Biol 17:798-818 
925 Holocene carbon accumulation and climate change from an equatorial peat bog (Kalimantan, 926 Indonesia): implications for past, present and future carbon dynamics. J Quaternary Sci 19:25-635

927 Pangala SR, Moore S, Hornibrook ERC, Gauci V (2013) Trees are major conduits for methane egress 928 from tropical forested wetlands. New Phytol 197:524-531

929 Parry LE, West LJ, Holden J, Chapman PJ (2014) Evaluating approaches for estimating peat depth. J 930 Geophys Res Biogeosciences 119:567-576

931 Phillips OL, Baker TR, Feldpausch T, Brienen R (2009) RAINFOR field manual for plot establishment 932 and remeasurement.

933 http://www.rainfor.org/upload/ManualsEnglish/RAINFOR_field_manual_version_June_2009_ENG.pdf 934 Accessed 10 September 2014.

935 Phillips S, Rouse GE, Bustin RM (1997) Vegetation zones and diagnostic pollen profiles of a coastal peat 936 swamp, Bocas del Toro, Panamá. Palaeogeogr Palaeoclim Palaeoecol 128:301-338

937 Phua MH, Tsuyuki S, Lee JS, Sasakawa H (2007) Detection of burned peat swamp forest in a 938 heterogeneous tropical landscape: A case study of the Klias Peninsula, Sabah, Malaysia. Landscape 939 Urban Plan 82:103-116

940 Pitkänen A, Turunen J, Simola H (2011) Comparison of different types of peat corers in volumetric 941 sampling. Suo 62:51-57

942 Price JS (2003) Role and character of seasonal peat soil deformation on the hydrology of undisturbed 943 and cutover peatlands. Water Resour Res 39:1241

944 Qualls RG, Haines BL (1990) The influence of humic substances on the aerobic decomposition of 945 submerged leaf litter. Hydrobiologia 206:133-138

946 Rakwatin P, Longepe N, Isoguchi O, Shimada M (2009) Potential of ALOS PALSAR 50m mosaic product 947 for land cover classification in tropical rain forest. Proceedings of the Asian Conference on Remote 948 Sensing (ACRS). 
Rosenqvist Å, Birkett CM (2002) Evaluation of JERS-1 SAR mosaics for hydrological applications in the Congo river basin. Int J Remote Sens 23:1283-1302

Roucoux KH, Lawson IT, Jones TD, Baker TR, Coronado EN, Gosling WD, Lähteenoja O (2013) Vegetation development in an Amazonian peatland. Palaeogeogr Palaeoecol 374:242-255

Roulet NT, Lafleurs PM, Richard PJH, Moore TR, Humphreys ER, Bubier J (2007) Contemporary carbon balance and late Holocene carbon accumulation in a northern peatland. Global Change Biol 13:397411

Saatchi SS, Harris NL, Brown S, Lefsky M, Mitchard ETA, Salas W, Zutta BR, Buermann W, Lewis SL, Hagen S, Petrova S, White L, Silman M, Morel A (2011) Benchmark map of forest carbon stocks in tropical regions across three continents. P Natl A Acad Sci USA 108:9899-9904

Sheng Y, Smith LC, MacDonald GM, Kremenetski KV, Frey KE, Velichko AA, Lee M, Beilman DW, Dubinin P (2004) A high-resolution GIS-based inventory of the west Siberian peat carbon pool. Global Biogeochem Cy 18:GB3004

Shimada S, Takahashi H, Haraguchi A, Kaneko M (2001) The carbon content characteristics of tropical peats in Central Kalimantan, Indonesia: estimating their spatial variability in density. Biogeochemistry $53: 249-267$

Shimamura T, Momose K (2005) Organic matter dynamics control plant species coexistence in a tropical peat swamp forest. Philos T R Soc B272:1503-1510

Sjögersten S, Cheesman AW, Lopez O, Turner BL (2011) Biogeochemical processes along a nutrient gradient in a tropical ombrotrophic peatland. Biogeochemistry 104:147-163

Sjögersten S, Black CR, Evers S, Hoyos-Santillan J, Wright EL, Turner BL (2014) Tropical wetlands: A missing link in the global carbon cycle? Global Biogeochem Cy 28. doi: 10.1002/2014GB004844

Slater LD, Reeve A (2002) Investigating peatland stratigraphy and hydrogeology using integrated electrical geophysics. Geophysics 67:365-378 
973

Sulistiyanto Y (2004) Nutrient Dynamics in Different Sub-types of Peat Swamp Forest in Central Kalimantan, Indonesia. Unpublished PhD thesis, University of Nottingham

Sundari S, Hirano T, Yamada H, Kusin K, Limin S (2012) Effect of groundwater level on soil respiration in tropical peat swamp forests. J Agric Meteorol 68:121-134

Suzuki S, Ishida T, Nagano T, Waijaroen S (1999) Influences of deforestation on carbon balance in a natural tropical peat swamp forest in Thailand. Environmental Control in Biology 37:115-128

Symbula M, Day FP Jr (1988) Evaluation of two methods for estimating belowground production in a freshwater swamp forest. Am Midl Nat 120:405-415

Tie YL, Esterle JS (1992) Formation of lowland peat domes in Sarawak, Malaysia. In: Aminuddin BY, Tan SL, Aziz B, Samy J, Salmah Z, Siti Petimah H, Choo ST (eds) Proceedings of the International Symposium on Tropical Peatland, 6-10 May 1991, Kuching, Sarawak, Malaysia. Kuala Lumpur: Malaysian Agricultural Research and Development Institute, pp. 81-89.

Turunen J, Tomppo E, Tolonen K, Reinikainen A (2002) Estimating carbon accumulation rates of undrained mires in Finland-application to boreal and subarctic regions. Holocene 12:69-80

van Asselen S, Roosendaal C (2009) A new method for determining the bulk density of uncompacted peat from field settings. J Sediment Res 79:918-922

Vasander H, Kettunen A (2006) Carbon in boreal peatlands. In: Wieder RK, Vitt DH (eds) Ecological Studies Vol. 188: Boreal Peatland Ecosystems, pp. 165-194. Berlin/Heidelberg: Springer-Verlag.

Waddell KL (2002) Sampling coarse woody debris for multiple attributes in extensive resource inventories. Ecol Indic 1:139-153

Wahyunto, Ritung S, Subagjo H (2003) Peta Luas Sebaran Lahan Gambut dan Kandungan Kargon di Pulau Sumatera/Maps of Area of Peatland Distribution and Carbon Content in Sumatera, 1990-2002. Bogor: Wetlands International - Indonesia Programme and Wildlife Habitat Canada (WHC).

Wahyunto, Ritung S, Sugagjo H (2004) Peta Sebaran Lahan Gambut, Luas dan Kandungan Karbon di 
Kalimantan/Map of Peatland Distribution Area and Carbon Content in Kalimantan, 2000-2002. Bogor:

Wetlands International - Indonesia Programme and Wildlife Jabitat Canada (WHC).

Wahyunto, Heryanto B, Widiastuti HBdF (2006) Peta Sebaran Lahan Gambut, Luas dan Kandungan Karbon di Papua/Maps of Peatland Distribution, Area and Carbon Content in Papua, 2000-2001. Bogor: Wetlands International - Indonesia Programme and Wildlife Habitat Canada (WHC).

Waldram MS (2014) Characterising Disturbance in Tropical Peat Swamp Forest Using Satellite Imaging Radar. Unpublished PhD Thesis, University of Leicester. http://hdl.handle.net/2381/28631

Warren MW, Kauffman JB, Murdiyarso D, Anshari G, Hergoualc'h K, Kurnianito S, Purbopuspito J, Gusmayanti E, Afifudin M, Rahajoe J, Alhamd L, Limin S, Iswandi A (2012) A cost-efficient method to assess carbon stocks in tropical peat soil. Biogeosciences 9:4477-4485

Wheeler BD, Proctor MCF (2000) Ecological gradients, subdivisions and terminology of north-west European mires. J Ecol 88:187-203

Wijedasa LS, Lahiru S, Sloan S, Michelakis D, Clements GR (2012) Overcoming limitations with Landsat imagery for mapping of peat swamp forests in Sundaland. Remote Sens 4:2595-2618

Woodall CW, Monleon VJ (2008) Sampling Protocol, Estimation, and Analysis Procedures for the Down Woody Materials Indicator of the FIA Program. USDA Forest Service, Newtown Square, Pennsylvania, USA.

Wright HE Jr (1991) Coring tips. J Paleolimnol 6:37-49

Wright EL, Black CR, Cheesman AW, Drage T, Large D, Turner BL, Sjögersten S (2011) Contribution of subsurface peat to $\mathrm{CO}_{2}$ and $\mathrm{CH}_{4}$ fluxes in a neotropical peatland. Global Change Biol 17:2867-2881

Wright EL, Black CR, Cheesman AW, Turner BL, Sjögersten S (2013a) Impact of simulated changes in water table depth on ex situ decomposition of leaf litter from a Neotropical peatland. Wetlands $33: 217-226$

Wright EL, Black CR, Turner BL, Sjögersten S (2013b) Diurnal and seasonal variation in $\mathrm{CO}_{2}$ and $\mathrm{CH}_{4}$ 
Wüst RA, Bustin RM (2004) Late Pleistocene and Holocene development of the interior peat1024 accumulating basin of tropical Tasek Bera, Peninsular Malaysia. Palaeogeogr Palaeoclim 211:241-270

Wüst RA, Bustin RM, Lavkulich LM (2003) New classification systems for tropical organic-rich deposits based on studies of the Tasek Bera Basin, Malaysia. Catena 53:133-163

Wüst RA, Ward CR, Bustin RM, Hawke MI (2002) Characterization and quantification of inorganic 1028 constituents of tropical peats and organic-rich deposits from Tasek Bera (Peninsular Malaysia): implications for coals. Int J Coal Geol 49:215-249

1030 Yoshioka T, Ueda S, Miyajima T, Wada E, Yoshida N, Sugimoto A, Vijarnsorn P, Boonprakub S (2002) 1031 Biogeochemical properties of a tropical swamp forest ecosystem in southern Thailand. Limnology $1032 \quad 3: 51-59$

1033 Yu Z (2012) Northern peatland carbon stocks and dynamics: a review. Biogeosciences 9:4071-4085

1034 Yule CM, Gomez LN (2008) Leaf litter decomposition in a tropical peat swamp forest in Peninsular 1035 Malaysia. Wetl Ecol Manag 17:231-241

\section{Table}

\begin{tabular}{|l|l|}
\hline Variable & Method(s) and key references \\
\hline Location & $\begin{array}{l} \pm 10 \mathrm{~m} \text { precision of good quality consumer-grade handheld } \\
\text { GPS or GPS/GLONASS units is adequate. }\end{array}$ \\
\hline Peat thickness & $\begin{array}{l}\text { Measurement by coring or augering, taking care to define } \\
\text { the base of the 'peat' using reproducible criteria, i.e. taking } \\
\text { ample samples for carbon concentration and loss-on- }\end{array}$ \\
\hline
\end{tabular}




\begin{tabular}{|c|c|}
\hline & ignition measurements: e.g. Parry et al. (2014). \\
\hline Peat carbon concentration & $\begin{array}{l}\text { Measured by elemental analysis, including samples from } \\
\text { the full range of peat depths: Chambers et al. (2011); } \\
\text { Chimner et al. (2014). }\end{array}$ \\
\hline Peat dry bulk density & $\begin{array}{l}\text { Each carbon concentration measurement should have an } \\
\text { associated dry bulk density measurement: see Chambers et } \\
\text { al. (2011). }\end{array}$ \\
\hline Canopy height & $\begin{array}{l}\text { Height of the ten tallest trees within } 20 \text { m of the core site, } \\
\text { measured using a clinometer and tape measure, or a laser } \\
\text { rangefinder: Phillips et al. (2009). }\end{array}$ \\
\hline Vegetation composition/structure & $\begin{array}{l}\text { Ideally, installation of a permanent } 0.5-1 \text { ha vegetation } \\
\text { sampling plot following RAINFOR protocols (Malhi et al. } \\
\text { 2002), extended where appropriate (e.g. to include small } \\
\text { trees, shrubs and herbs where these are important, and } \\
\text { coarse woody debris). Where this is impractical, a general } \\
\text { description of the vegetation structure and dominant } \\
\text { species within } 20 \text { m of the core site is sufficient for most } \\
\text { remote sensing studies. }\end{array}$ \\
\hline
\end{tabular}

Table 1. A suggested protocol for site description which facilitates basic data comparison, and development/testing of remote sensing techniques for peatland mapping and characterization.

\section{Figure captions}

1040 Figure 1. Distribution of the peat carbon pool in the tropics, based on country-scale estimates from 1041 Page et al. (2011b; dotted regions indicate no data). In Australia, the estimate refers to the state of 1042 Queensland only. Examples of lowland peatlands discussed in the text are indicated as follows: SSPS: 
1043 San San Pond Sak, Panama; PMF: Pastaza-Marañón Foreland, Peru; CC: Cuvette Centrale, Republic of 1044 Congo/Democratic Republic of Congo; TB: Tasek Bera, Malaysia; K: Kalimantan, Indonesia.

1045 Figure 2. Vegetation classification of the Changuinola peat dome in the San San Pond Sak tropical 1046 peatland, Panama, using Landsat Thematic Mapper imagery, supported by both aerial photographs 1047 and field data as sources of reference.

1048 Figure 3. Dry bulk density (DBD) values from published peat sequences. The box plots show the range 1049 of the data (dashed bars) and the lower, middle and upper quartiles (horizontal lines); the width of the 1050 bars is proportional to the square root of the size of each dataset (the total number of samples is 90); 1051 outliers are shown as circles. Only data from peats with $<10 \%$ ash are shown. Note that the Sebangau 1052 peatland is in Indonesia; all other peatlands are from the Peruvian Amazon. Data sources: Wüst et al. 1053 2002, 2003; Page et al. 2004; Lähteenoja et al. 2009a; Lähteenoja and Page, 2011.

1054 Figure 4. Dry bulk density and ash content from core SA6.5, Kalimantan, Indonesia (Page et al. 2004), 1055 illustrating stratigraphic variation in DBD values.

1056 Figure 5. Organic carbon values from published peat sequences (references and symbols as for fig. 2). 1057 Only data from peats with $<10 \%$ ash are shown. Note that all records are from the Peruvian Amazon, 1058 except Tasek Bera (Malaysia) and Sebangau (Indonesia). Data sources: Wüst et al. 2002, 2003; Page et 1059 al. 2004; Lähteenoja et al. 2009; Lähteenoja and Page, 2011.

1060 Figure 6. Carbon density measured using an elemental analyser plotted against ash content 1061 determined by loss-on-ignition (LOI) for some tropical peats. The straight line indicates the 1062 relationship used by Turunen et al. (2002) to estimate carbon content from LOI data. Only data from 1063 peats with < $10 \%$ ash are shown. Data sources: Wüst et al. 2002, 2003; Page et al. 2004; Lähteenoja et 1064 al. 2009a; Lähteenoja and Page, 2011. 
1066 Fig. 1

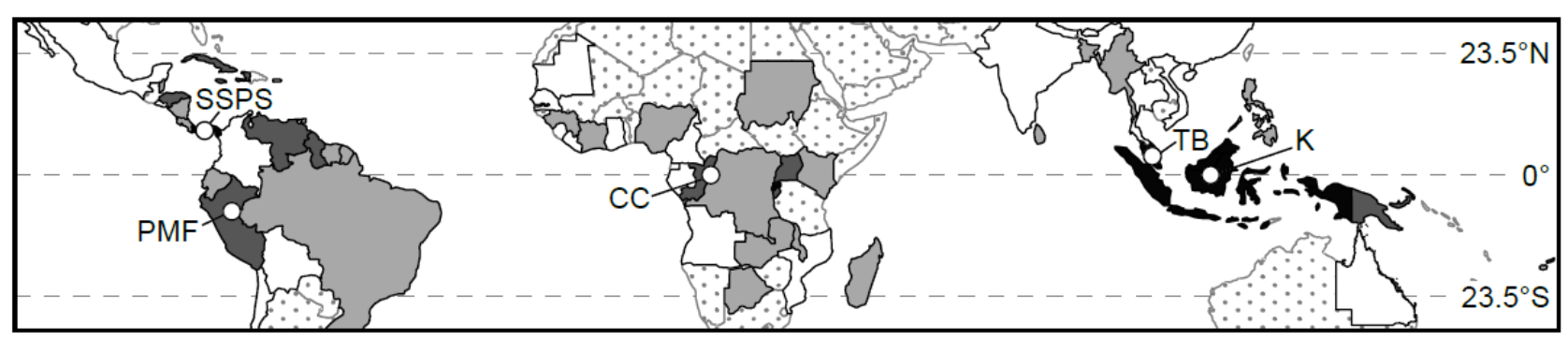

Area-specific peat carbon pool ( $\left.\mathrm{Mg} \mathrm{C} \mathrm{km}^{-2}\right)$

$\square$ 0-100

$100-1000$

$1000-10,000$

1067

$>10,000$

1068 
Fig. 2
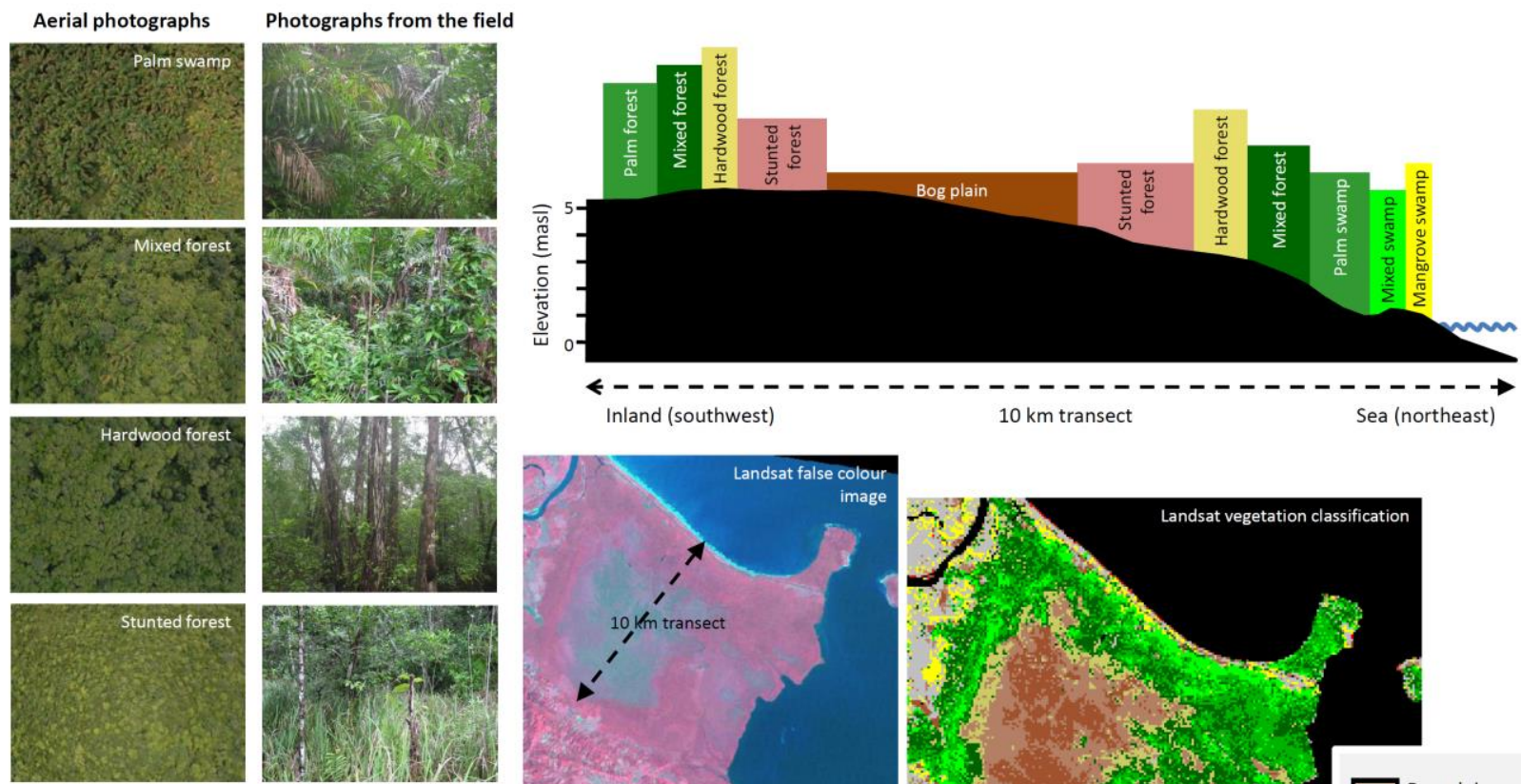

Bog plain
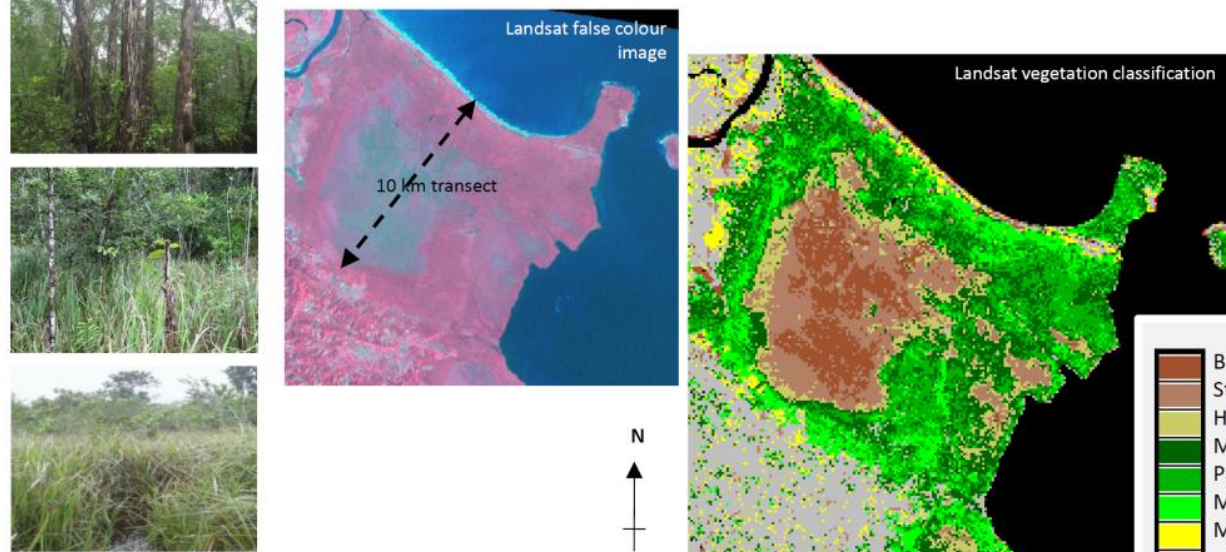

N

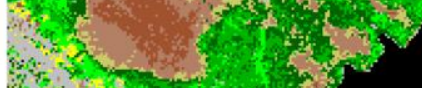
Bog plain
Hardwood forest
Mixed forest

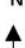

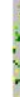

Palm swamp

1070

Mangrove 


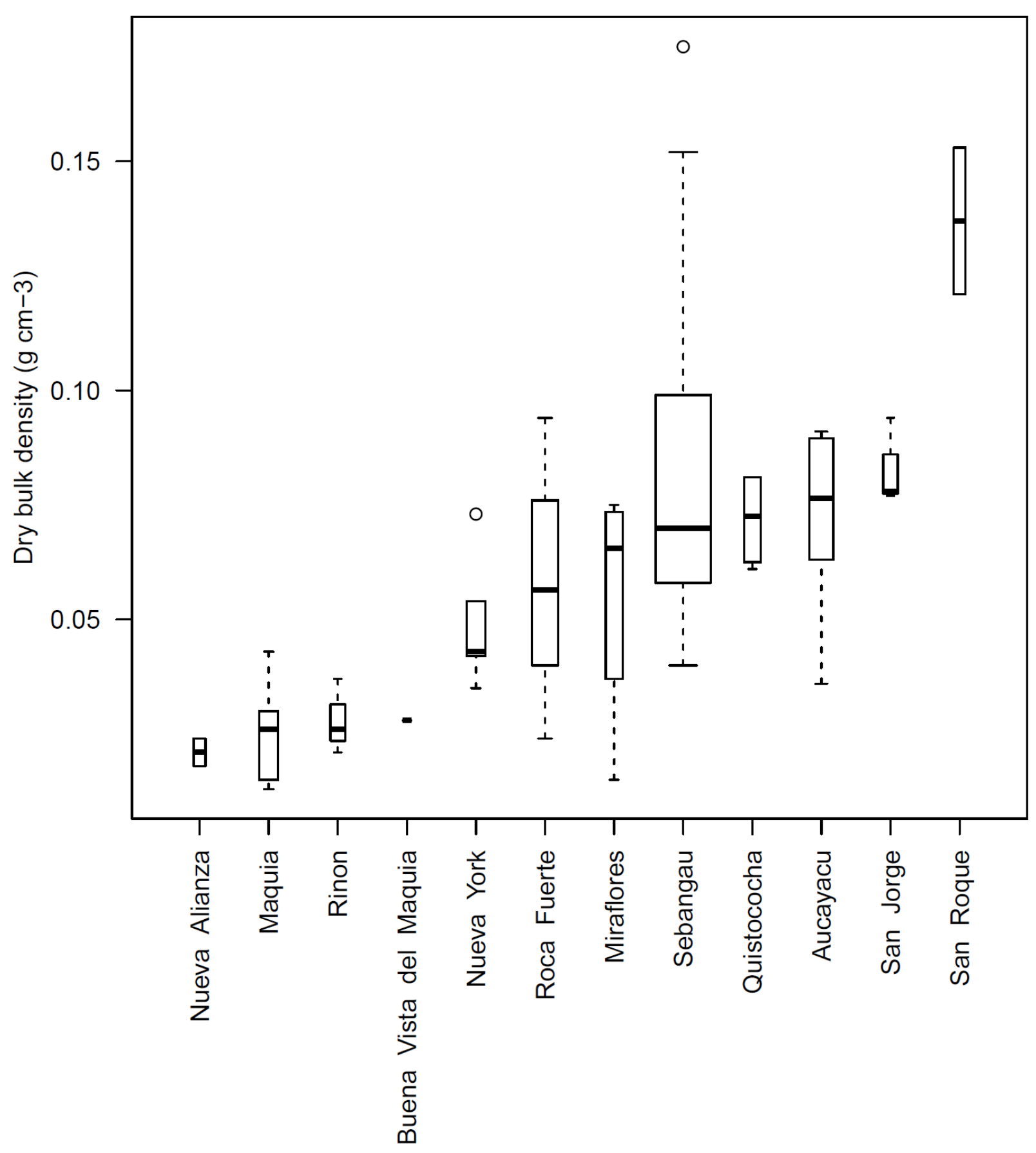

1073 
$1075 \quad$ Fig. 4

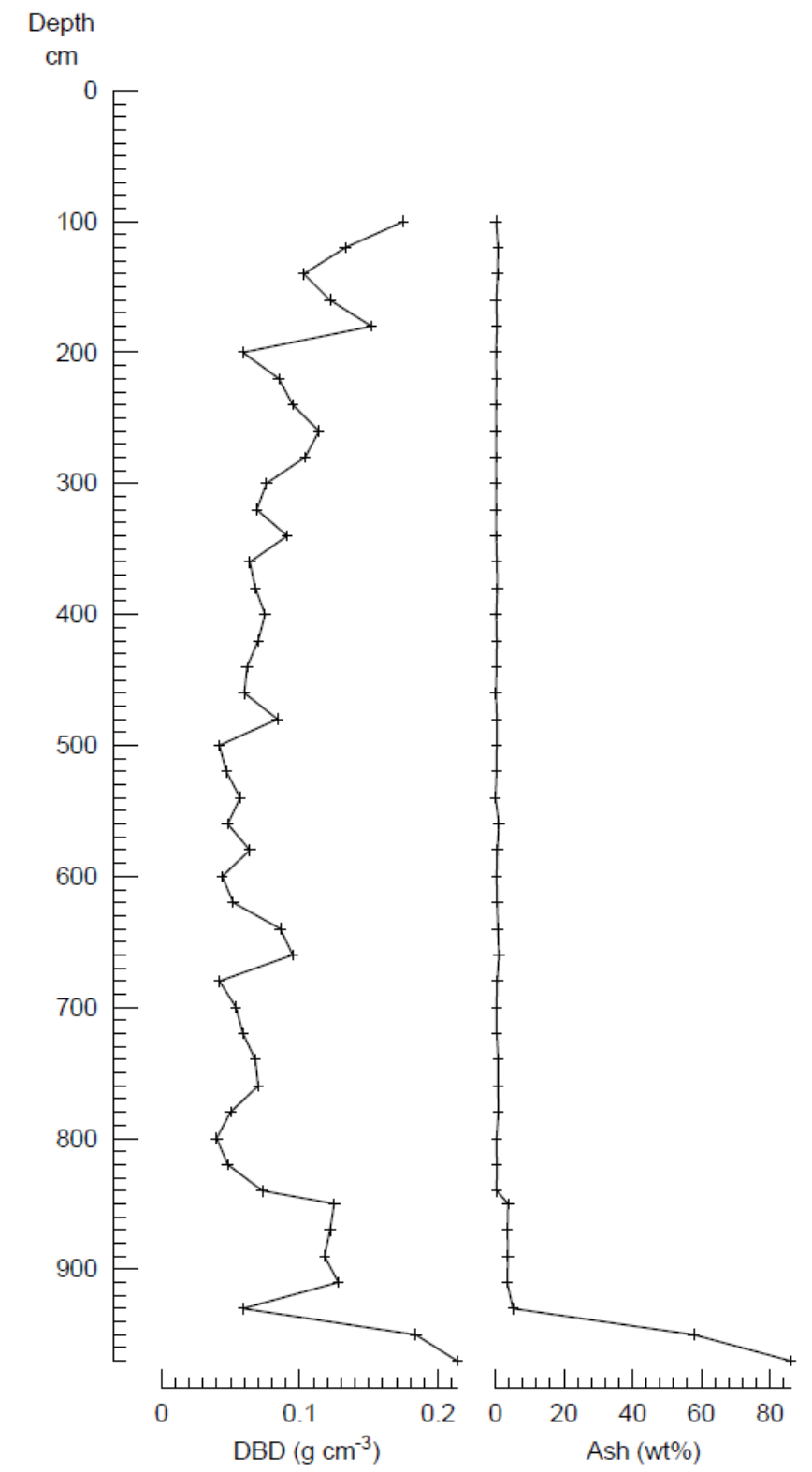

1076 


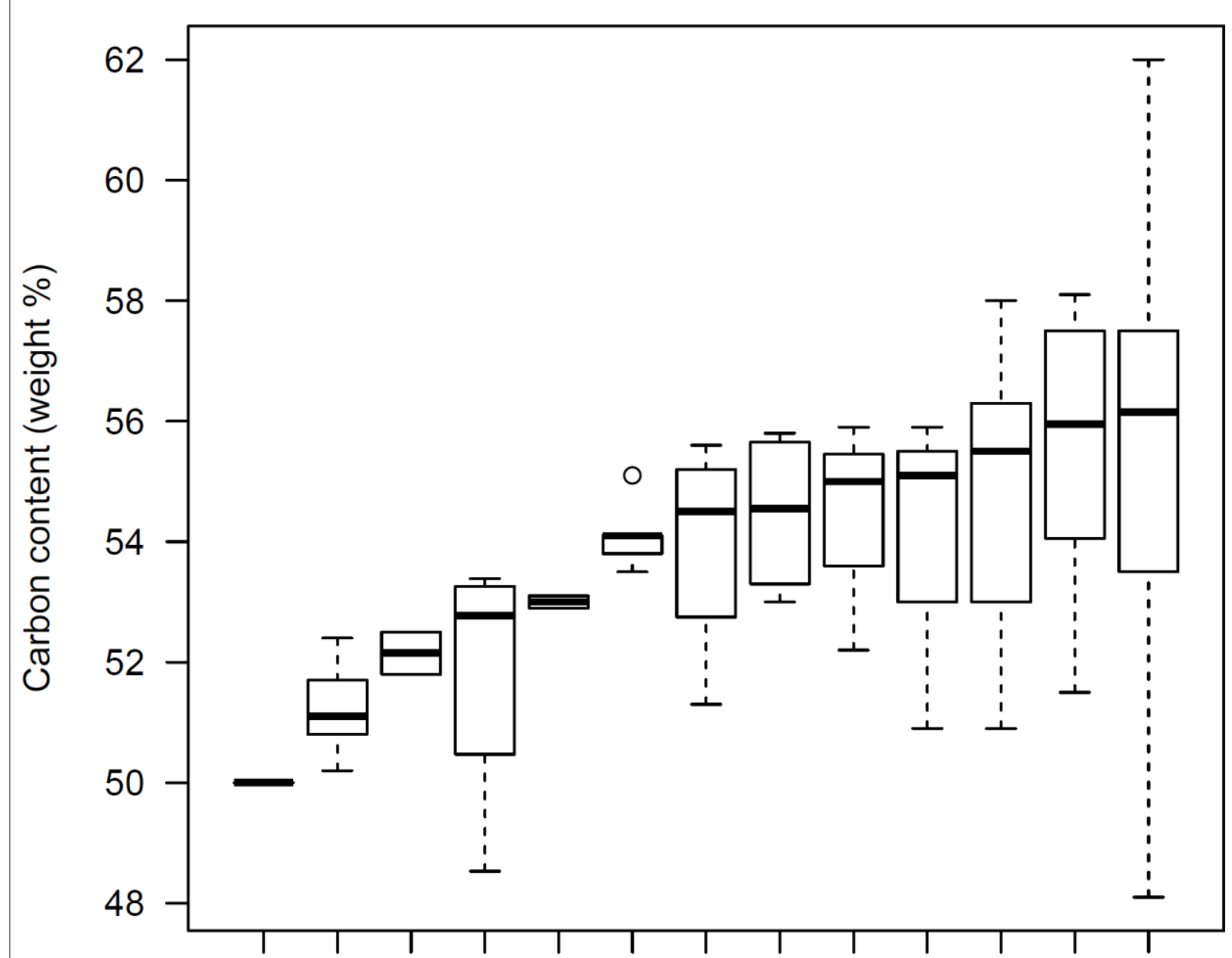




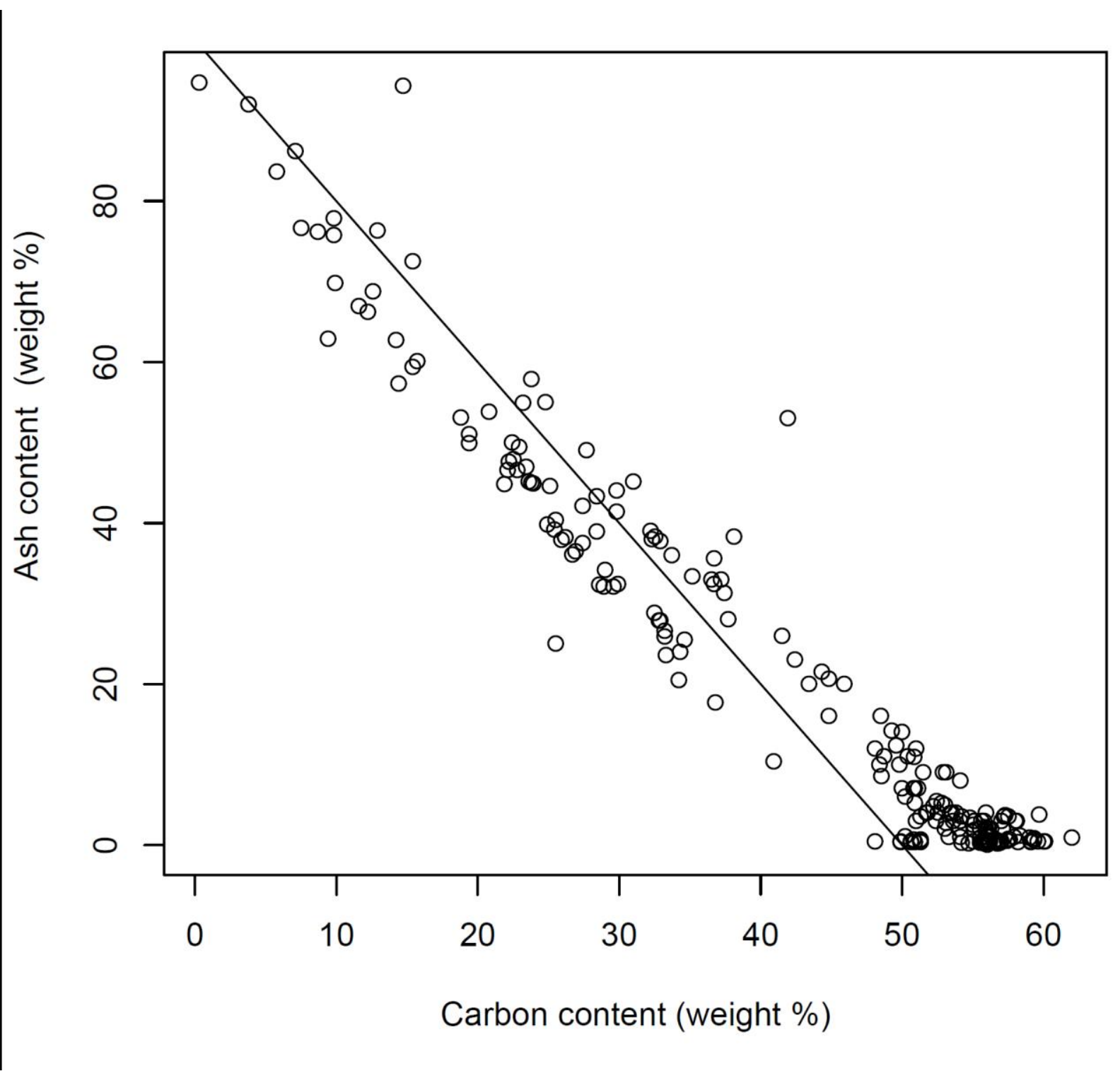

